\title{
O Plano Especial Diagonal-Poble Nou: da importância do protagonismo público na gestão e produção do espaço urbano à emergência do Urbanismo liberal (I)
}

The Diagonal-Poble Nou Special Plan: from the importance of public leadership in the management and production of urban space to the emergence of liberal urbanism (I)

Adelita Araujo [a] [D, Eunice Helena Sguizzardi Abascal [b] [D], Jane Victal [a] $[$ D, Joaquín Sabaté [c] [iD

[a] Pontifícia Universidade Católica de Campinas (PUC-Campinas), Campinas, SP, Brasil

[b] Universidade Presbiteriana Mackenzie, São Paulo, SP, Brasil

[c] Universidad Politécnica de Cataluña, Barcelona, Catalunha, Espanha

Como citar: Araujo, A., Abascal, E. H. S., Victal, J., \& Sabaté, J. (2021). O Plano Especial Diagonal-Poble Nou - da importância do protagonismo público na gestão e produção do espaço urbano à emergência do Urbanismo liberal. Urbe. Revista Brasileira de Gestão Urbana, v. 13, e20190364. https://doi.org/10.1590/2175-3369.013.e20190364

\section{Resumo}

Um passeio pela última seção da Avenida Diagonal em Barcelona, revendo alguns dos principais projetos desenvolvidos nos últimos anos, permite avaliar a política urbana da cidade como uma história de luzes e sombras, de notáveis operações de transformação, mas também de importantes dívidas sociais. Um desses projetos, o Plano Especial Diagonal-Poble Nou, conduz a intervenção urbana que concluiu a principal avenida da cidade, que corta o antigo bairro Poble Nou à margem do centro, com um rico e significativo patrimônio industrial. A abertura da Diagonal, respeitando o plano histórico de Cerdà, permite uma nova configuração do tecido urbano e induz um novo ordenamento em todo seu entorno. 0 objetivo deste artigo é analisar a abordagem na elaboração do Plano Especial Diagonal-Poble Nou, como representativo do Urbanismo praticado em Barcelona nos anos de 1980. Ao mesmo tempo demonstra como os câmbios introduzidos na aprovação do Plano Especial promovem uma mudança de paradigma e a adoção de um pensamento Urbanístico liberal, reduzindo a responsabilidade pública na gestão e produção do espaço urbano. A metodologia utilizada neste artigo envolveu revisão bibliográfica e análise aprofundada dos documentos do planeamento em seu contexto histórico.

Palavras-chave: Diagonal-Poble Nou. Urbanismo liberal. Projeto urbano.

\section{Abstract}

A walk through the last section of Diagonal Avenue in Barcelona, reviewing some of the major projects developed for it in recent years, allows us to evaluate the city's urban policies as a history of lights and shadows, of

AA é arquiteta, doutora em Arquitetura e Urbanismo, e-mail: adelitaaraujo@hotmail.com

EHSA é arquiteta, doutora em Arquitetura e Urbanismo, e-mail: eunicehab@gmail.com

JV é arquiteta, doutora em Arquitetura, e-mail: janevictal@puc-campinas.edu.br

JS é arquiteto e economista, doutor em Arquitetura e Urbanismo, e-mail: joaquin.sabate@upc.edu 
remarkable interventions, but also important social debts. One of such projects, the Diagonal Poble Nou Special Plan, led to the completion of the city's main avenue, which runs through the old tissue of Poble Nou, a downtown district with a rich and significant industrial heritage. The opening of Diagonal Avenue, respecting the historical plan of Cerdà, allowed a new configuration of the urban fabric and brought a new order in all its surroundings. The aim of this paper is to analyse how the elaboration of the Diagonal Poble Nou Special Plan is faced, as a representative of the urban planning practised in Barcelona in the 1980s. At the same time, it shows how the changes introduced at the Plan's approval; imply a paradigm's change and a turn towards a more liberal urbanism, reducing public responsibility in the management and production of urban space. The methodology involved a literature review and in-depth analysis of the planning documents at their historical context.

Keywords: Diagonal-Poble Nou. Urban Project. Liberal urbanism.

\section{Introdução}

Vários autores argumentam a mudança que ocorre na política urbana do Município de Barcelona no final dos anos 80, que em síntese pode ser caracterizada pelo surgimento de uma orientação liberal ao seu urbanismo, a transferência do protagonismo em favor dos grandes operadores imobiliários e a redução na dimensão social que havia caracterizado o urbanismo de Barcelona até então. Sobre isso podemos citar um artigo muito detalhado (Sabaté, 2006), em que o autor analisa um extenso conjunto de publicações municipais entre 1983 e 19991. Outros autores também o fizeram, discutindo o chamado modelo de Barcelona (Bonet \& Domingo, 2005; Delgado, 2007; Capel, 2005; Sabaté, 2007, 2008; Sabaté e Tironi, 2008; Montaner et al., 2011), a abertura da Avenida Diagonal (Sabaté, 1997; CCRS, 1986), ou os projetos urbanos desenvolvidos na Catalunha na época (Corominas et al., 2007; Sabaté, 1997, 2003).

O que gostaríamos de apresentar são alguns dados específicos do Plano Especial Diagonal-Poble Nou, que reafirmam tendências já discutidas há mais de duas décadas. Este artigo foi desenvolvido com base na experiência do diretor da equipe que elaborou o Plano Especial Diagonal-Poble Nou. 0 município encomendou em 1986 o referido Plano Especial ao Escritório de Arquitetura e Urbanismo CCRS, uma empresa com ampla experiência em planeamento, composta por um grupo de urbanistas e professores do Departamento de Urbanismo da Universidade Politécnica de Catalunha (Isabel Castiñeira, Miquel Corominas, Francesc Ragués e Joaquín Sabaté). O Plano foi apresentado pela equipe em 1987, mas posteriores mudanças postergaram sua aprovação definitiva até o ano de 19932.

O Plano Especial desenvolve as projeções do Plano Geral Metropolitano, que determinou sua área, seus usos e sua intensidade de construção. Desenhou-se a partir de uma rigorosa pesquisa de campo, que envolveu o levantamento detalhado de todas as propriedades da área, identificando construções e atividades instaladas, exigindo um ano e meio de investigações prévias. No método adotado, estudos morfológicos tiveram papel central, criando as bases da futura proposta de intervenção.

Sabaté (Sabaté et al., 2016) explica que os primeiros estudos com metodologia morfológica no escritório foram essencialmente inspirados em trabalhos pioneiros como os de Ian L. McHarg, Design with

\footnotetext{
${ }^{1}$ Ayuntamiento de Barcelona 1983a, 1983b, 1984, 1987a, 1987b, 1987c, 1989, 1990a, 1990b, 1993a, 1993b, 1993c, 1994, 1996, 1999.

${ }^{2} 0$ município de Barcelona sempre foi o responsável pela aprovação dos planos de desenvolvimento e transformação urbanística. Entretanto, naquela época, era comum encomendar a sua elaboração aos escritórios de urbanismo mais qualificados da cidade. Habitualmente o escritório apresenta os avanços aos técnicos municipais, e ao público quando atinge um nível de especificidade suficiente, em um processo denominado Avanço. Isso serve para coletar sugestões de todos os agentes envolvidos e cidadãos interessados. O Plano volta a ser exposto ao final do processo de elaboração, quando o município o aprova inicialmente. Esses documentos contêm uma definição morfológica muito precisa, quase no nível da arquitetura; um regulamento de construção muito completo, bem como estudos de viabilidade económica e normas detalhadas para a gestão de todo o processo de urbanização e construção, que envolverá atores públicos e privados.
} 
Nature (McHarg, 1967), ou de Kevin Lynch, The image of the city (Lynch, 1960), que utilizaram análises morfológicas como meio de medir a capacidade do território de suportar determinadas atividades.

Com o tempo, esses estudos foram se ampliando, ajustando objetivos, sendo o desenho cuidadosamente direcionado à prática do urbanismo, com leituras intencionadas ao projeto e ao planeamento, no intuito de (re)estruturar territórios, paisagens e áreas urbanas. Nas palavras de Solà-Morales, um dos grandes teóricos dessa metodologia, "Desenhar é selecionar, selecionar é interpretar, interpretar é projetar" (Solà-Morales, 1981. Tradução nossa). Em pesquisas mais atualizadas, Sabaté declarou: "...o desenho não é apenas uma representação do que existe ou existiu, mas serve também para construir, transmitir ideias e interpretações" (Sabaté, 2016, p. 15, tradução nossa). 0 ato de desenhar o território, o urbano ou o rural não é apenas para explicar a sua formação, para compreendê-lo, mas também para projetá-lo. Desta forma, o desenho é pensado como uma narrativa carregada de significados, capaz de atuar na construção de futuros projetos.

Esses estudos e reflexões sobre o papel da morfologia urbana impulsionaram modelos, conceitos, ferramentas e técnicas disciplinares para análise e projeto, conduzindo o desenho morfológico como peça central na atividade acadêmica e profissional.

Atualmente, a importância dessa metodologia é claramente reconhecida, sendo aplicada na graduação e no Programa da Pós-Graduação em Planeamento Urbano (MPU) da UPC-Barcelona e se estende também ao European Postgraduate Masters of Urbanism (EMU) ${ }^{3}$.

É a partir desse contexto que esse artigo se foca em apresentar o projeto de transformação dessa área tão complexa de Barcelona, utilizando a aproximação histórico-analítica e a análise do projeto urbano aplicado no Plano Especial Diagonal-Poble Nou.

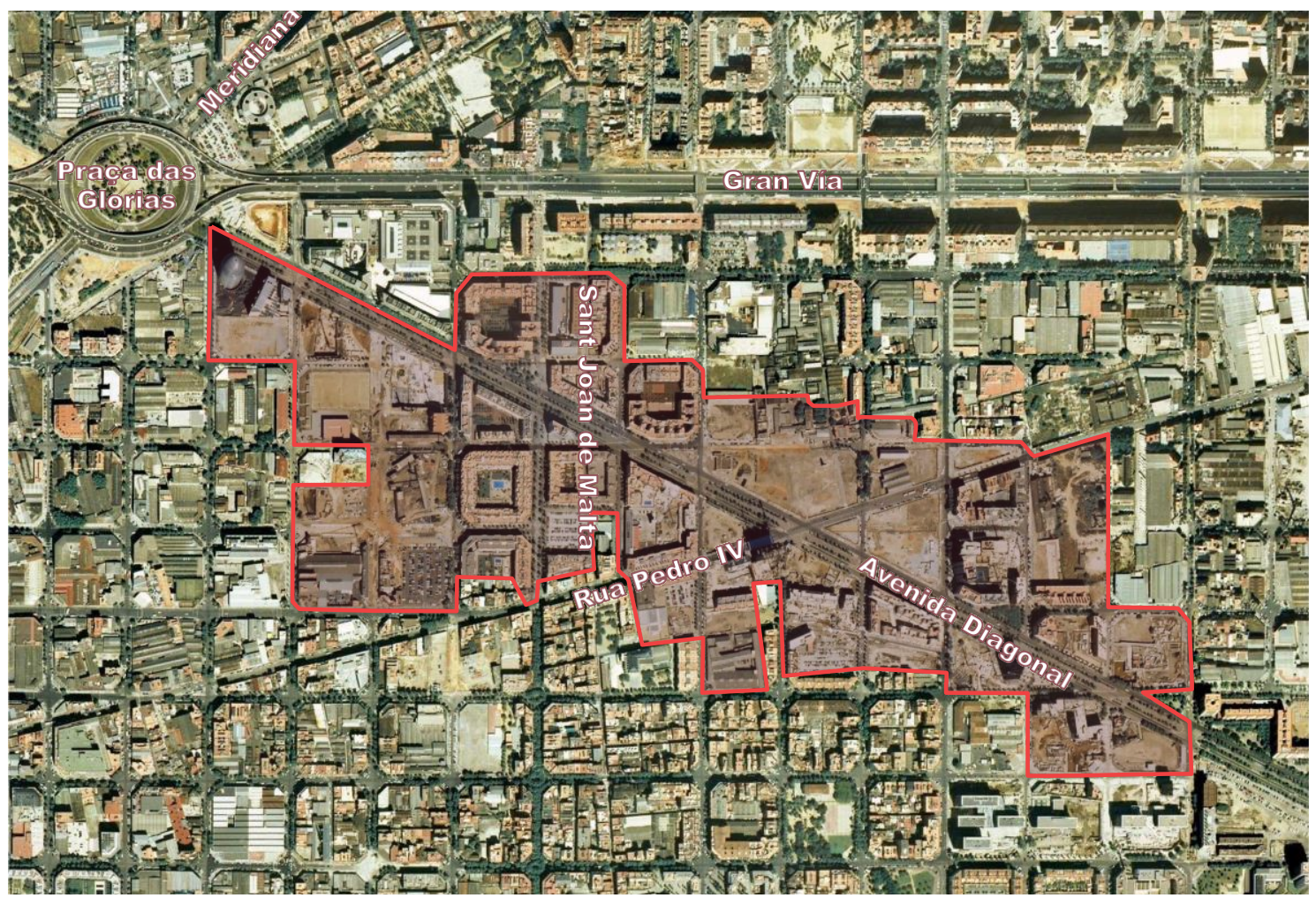

Figura 1 - Imagem aérea de Poble Nou. Fonte: Google Maps (2000).

${ }^{3}$ Programa que envolve um esforço coletivo de quatro universidades europeias. 


\section{A abertura da Avenida Diagonal}

Atualmente a Avenida Diagonal tem cerca de dez quilômetros. Parte do extremo oeste da Barcelona e com diferentes seções atravessa completamente a cidade até alcançar o mar. Entretanto, há apenas trinta anos, antes das transformações promovidas pelo Plano Especial, o Poble Nou era muito diferente deste que observamos agora.

Em 1859, Ildefonso Cerdà, em seu plano de expansão da cidade de Barcelona (Projeto Ensanche), projeta a Avenida Diagonal como elemento estruturante, desenvolvendo sobre o bairro Poble Nou a mesma malha homogênea de ruas e quadras presente no resto da cidade. Cerdà concebeu um novo centro, precisamente no cruzamento da Avenida Diagonal com a Gran Vía, na Praça das Glorias. No entanto, mais de 130 anos depois, em pleno século XX, a Avenida Diagonal permanecia sem se consolidar.

O velho bairro operário industrial de Poble Nou, conhecido como o "Manchester Catalão", vinha crescendo muito perto da cidade central, mas de costas para ela, separado pela barreira artificial dos trilhos da ferrovia (Figura 1). Um amálgama de residência popular, indústrias de todo tipo e tamanho, e oficinas de artesanato havia se encaixado à área agrícola tradicional, na qual inclusive se mantinham várias hortas. Neste contexto, as propostas do Plano Regional de 1953 e do vigente Plano Metropolitano de 1976 optam por manter o traçado da Avenida Diagonal. Este último plano propôs intervir para transformar um setor de cerca de 70 hectares (o equivalente a aproximadamente sessenta quarteirões do plano Cerdà), onde se construiriam $820.000 \mathrm{~m}^{2}$ para habitação, 6.000 casas com $80 \mathrm{~m}^{2}$ de superfície média, para cerca de 20.000 pessoas, reservando $180.000 \mathrm{~m}^{2}$ para usos do setor terciário e industrial. Entretanto, quinze anos se passaram sem essas previsões se tornarem eficazes.

Do ponto de vista operativo, a principal dificuldade no desenvolvimento e na implantação do projeto na área eram as intervenções que deveriam ser promovidas na cidade já construída (Figura 2). Para abertura da Avenida Diagonal, mais de 1.000 moradores precisariam ser realocados; existiam 60.000 metros quadrados de atividade comercial instalada, antigas edificações e armazéns industriais, com cerca de 600 atividades em pleno funcionamento (Sabaté, 1986). É perante essas circunstâncias que a Prefeitura de Barcelona encomenda o Plano Especial Diagonal-Poble Nou para a empresa CCRS, buscando desenvolver uma reforma substancial na última área de notável extensão em Barcelona, submetida, além disso, a uma crescente pressão motivada pela transformação olímpica.

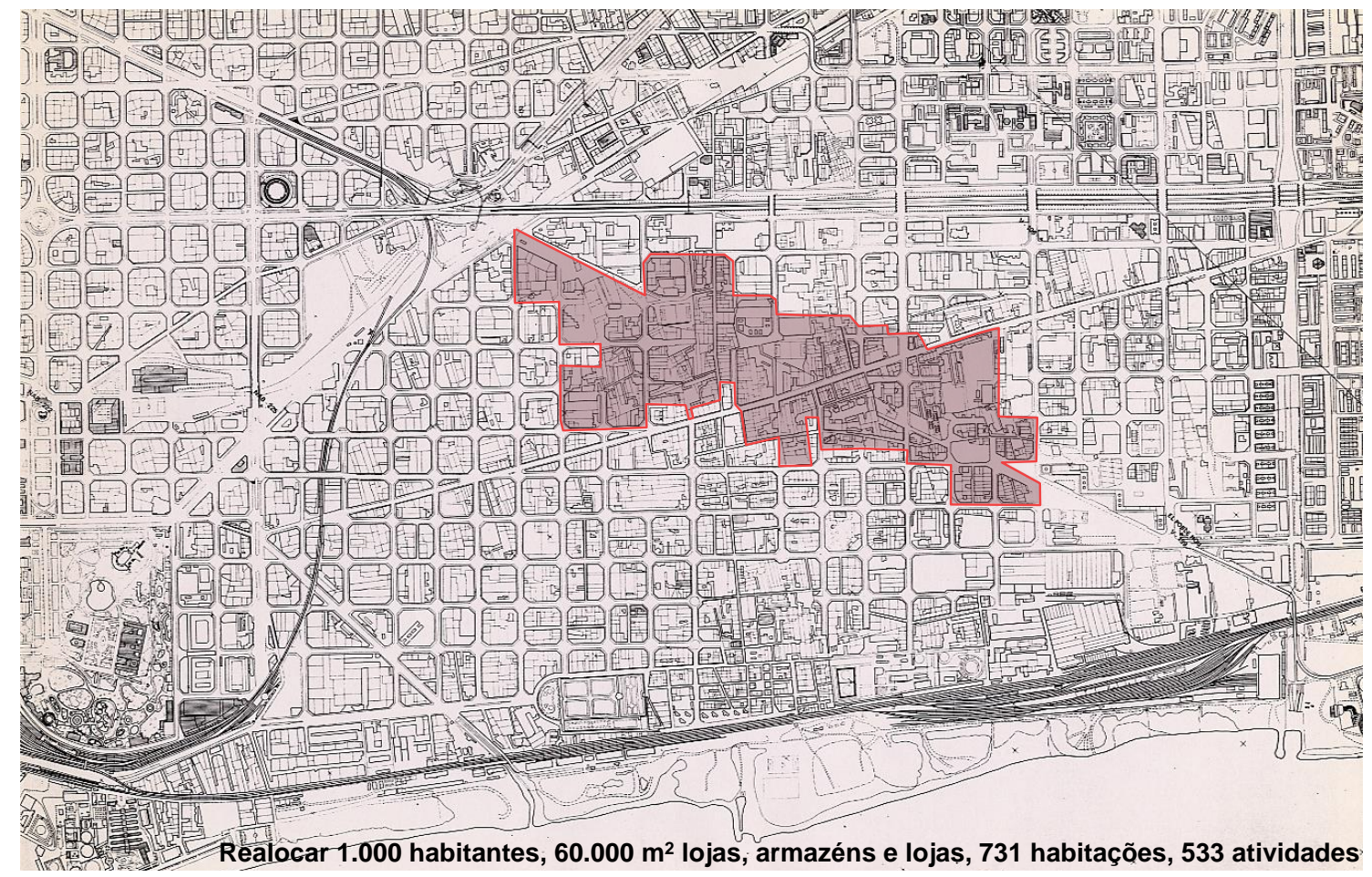

Figura 2 - Situação de área em 1986. Fonte: CCRS Arquitetos (1986). 
Mas como se aborda um projeto de transformação urbana em uma área tão complexa, e repleta de construções pré-existentes?

Este projeto de intervenção urbana é um dos mais representativos do Urbanismo da década de 1980, pois confia em uma metodologia morfológica que analisa o processo de formação de seus tecidos urbanos e valoriza minuciosamente suas características, colocando em destaque a superposição das tramas agrícolas, industriais e residenciais, avaliando o grau de obsolescência e de resistência à transformação de sua conformação física e de suas atividades (Figura 3). Outro aspecto considerado é o estudo das necessidades dos residentes e usuários direta ou indiretamente implicados (75.000 pessoas). Com base nisso, o projeto desenvolve cinco leituras simultâneas:

1. 0 processo histórico de formação do território ${ }^{4}$

2. A sobreposição de tramas que o caracteriza (forma) ${ }^{5}$

3. Avaliação de resistência à transformação de edifícios e atividades (dinâmicas) ${ }^{6}$

4. A qualidade dos espaços livres (espaço público) ${ }^{7}$

5. As necessidades de 75.000 residentes (pessoas) ${ }^{8}$

Uma breve revisão dessas leituras morfológicas nos permite apresentar o território antes de explicar o projeto.

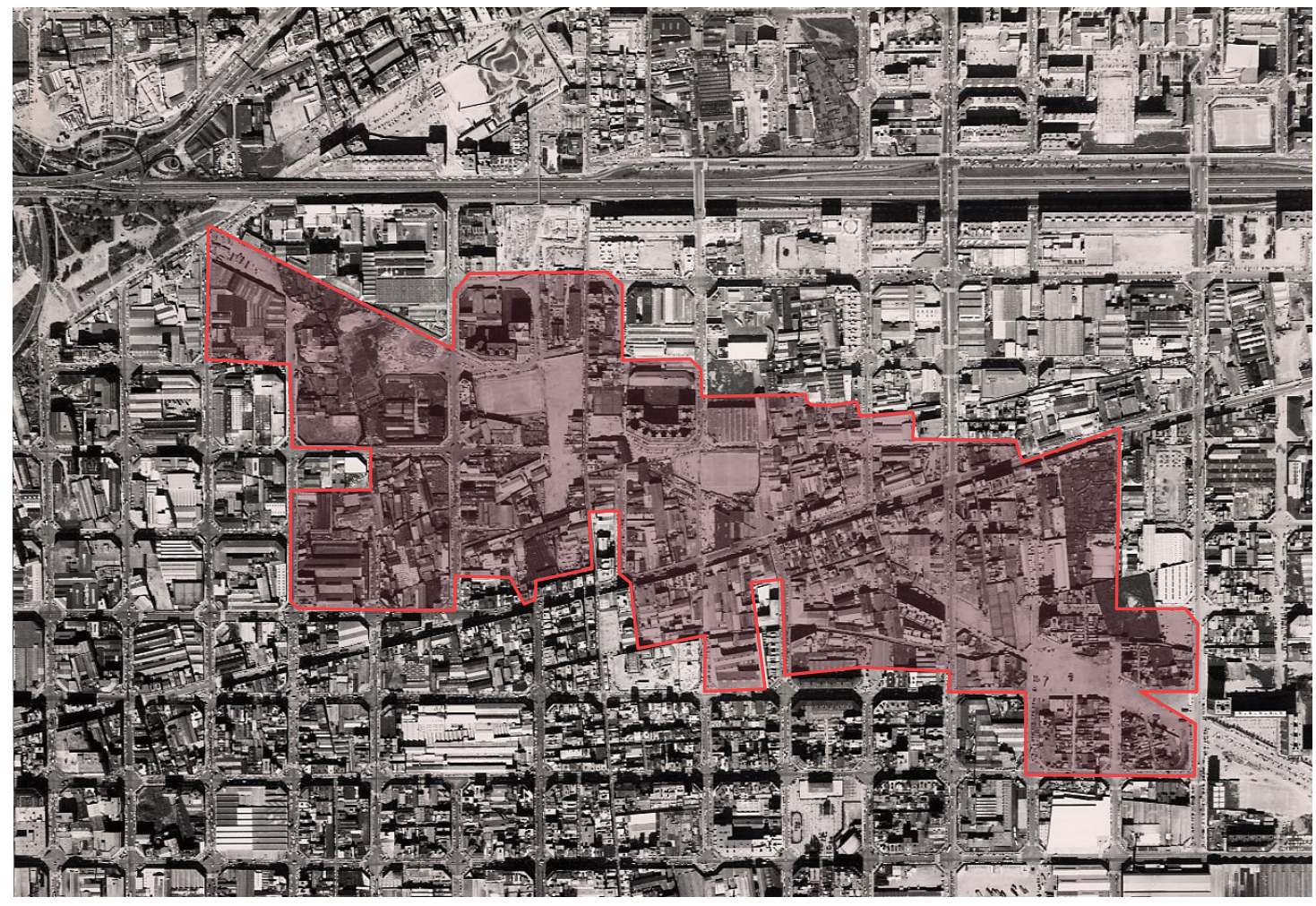

Figura 3 - Imagem aérea de 1986. Fonte: CCRS Arquitetos (1986).

\section{O processo de formação histórico do território}

O Poble Nou, um dos 10 bairros de Sant Martin, independente de Barcelona até 1897, sempre foi muito caracterizado por seu baixo nível em relação ao mar. A dois quilômetros da costa, seu território se eleva a apenas cinco metros de altitude, o que durante séculos resultou em áreas inundáveis.

\footnotetext{
4 Desenhando sobre o mapa atual cerca de vinte mapas históricos, dos quais apenas dois deles são mostrados no artigo. ${ }^{5}$ Desenhando o mapa cadastral, com milhares de propriedades, em três momentos históricos, para avaliar como o território é transformado.

${ }^{6}$ Avaliando com precisão à resistência de cada uma das construções e atividades à futura transformação, seja ela qual for.

7 Desenhando uma rede estruturada de espaços e dotações públicas.

${ }^{8}$ Avaliando as características da futura população e suas necessidades.
} 
Mas a história da construção deste território começa muito antes, com importantes ações de drenagem, defesa e consolidação de pântanos. Entre os anos de 954 e 966, o Conde Miró promoveu a construção de um enorme canal, com o objetivo de trazer as águas do Rio Besos à vizinha cidade de Barcelona e regar os campos percorridos por ele. Isto permitiu uma ampliação considerável de terra. A Figura 4 mostra a área analisada, terras agrícolas irrigadas com as águas do referido canal.

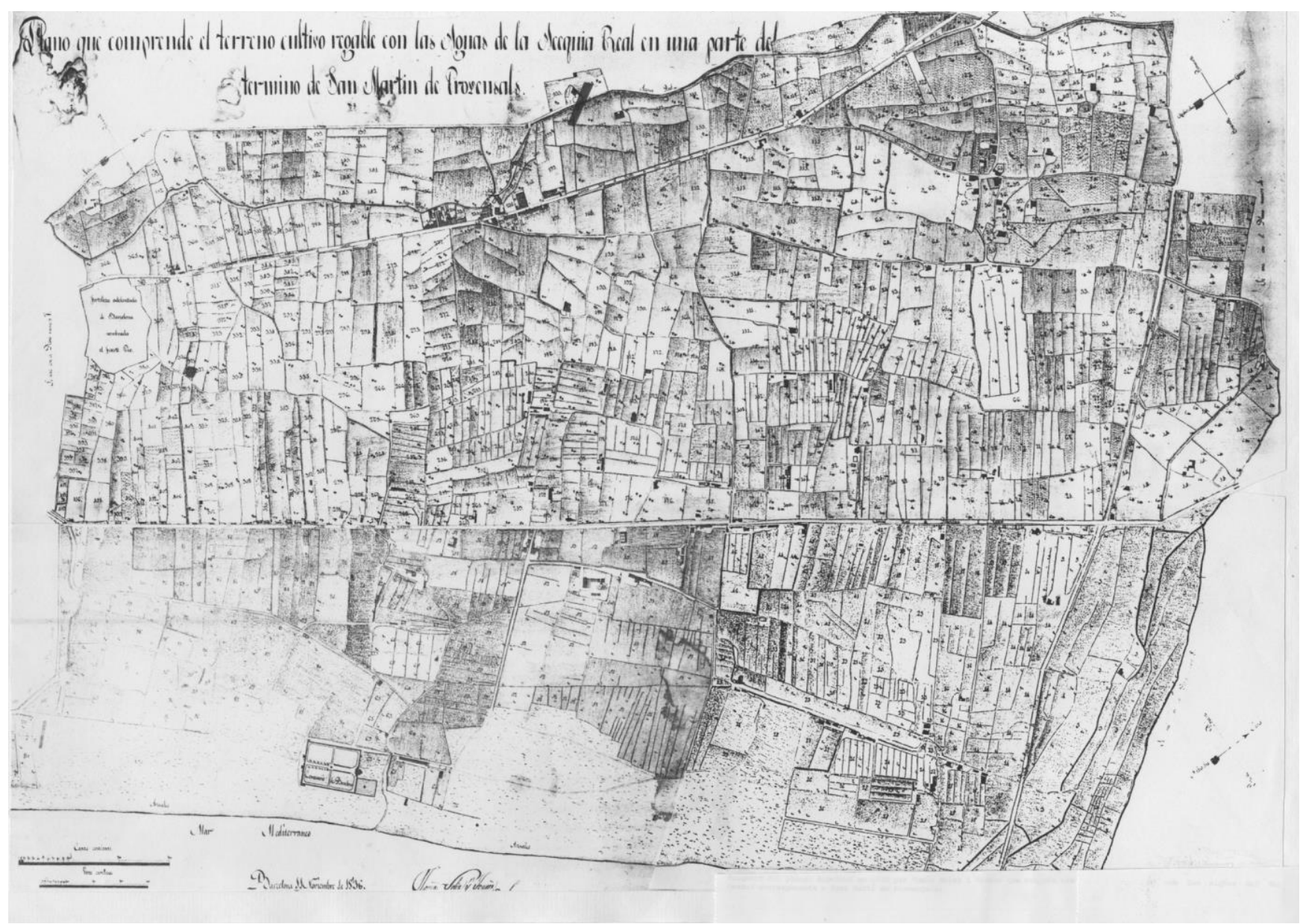

Figura 4 - El Rec Comptal (Canal). Tomas Soler i Ferrer, 1836. Fonte: Instituto Cartográfico de Catalunha. 


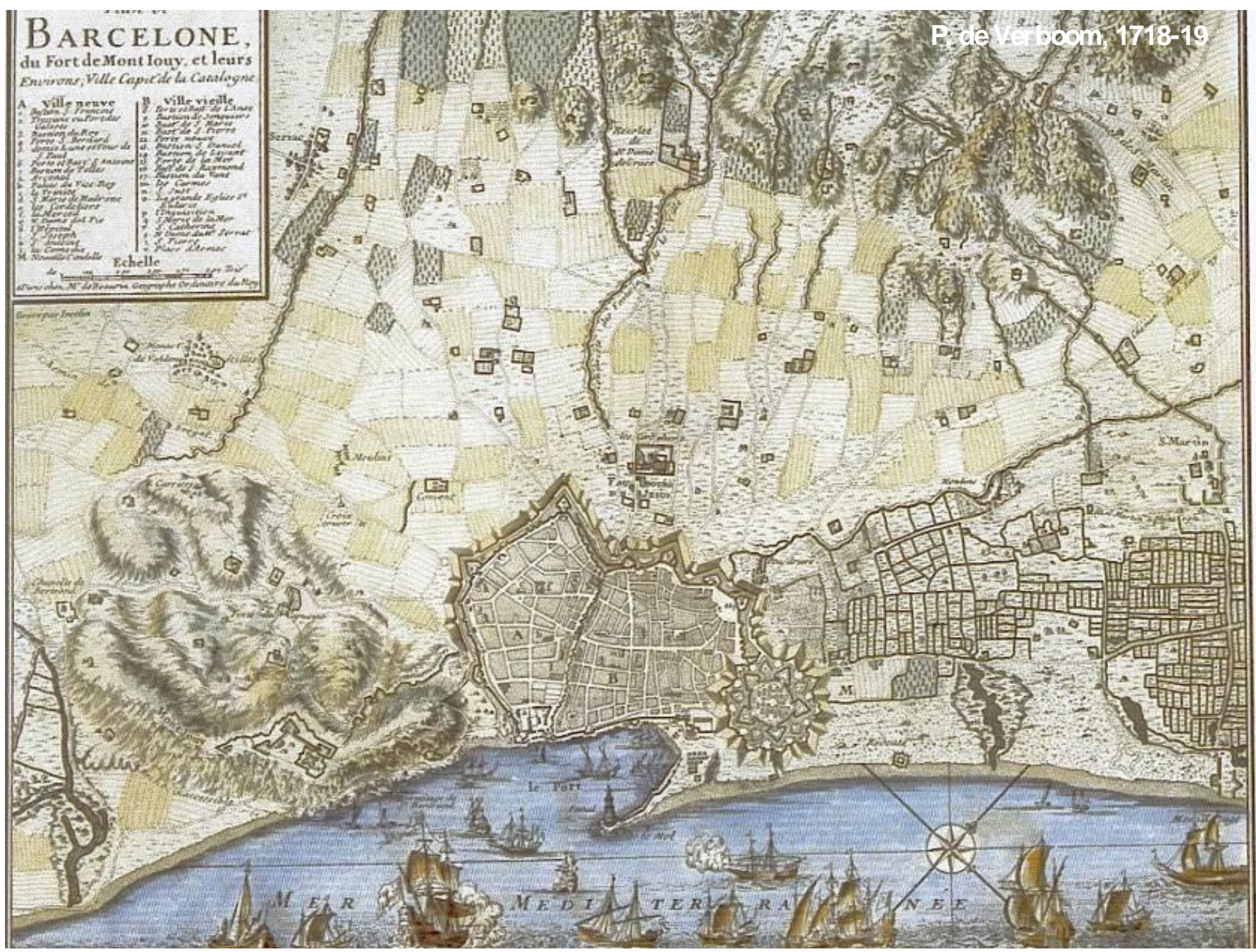

Figura 5 - Barcelona em 1718. Fonte: Instituto Cartográfico de Catalunha.

A Figura 5 enfatiza o valor agrícola e a condição de alagamento do território ${ }^{9}$.

0 mapa topográfico de Cerdà do ano de 1855 atesta a riqueza agrícola destas terras, um rico mosaico de parcelas de cultivo, orientadas segundo o traçado do canal.

${ }^{9} \mathrm{~A}$ análise e o redesenho de outros vinte mapas históricos nos permitiram traçar o cadastro em meados do século XIX, em 1881 e em 1929. 


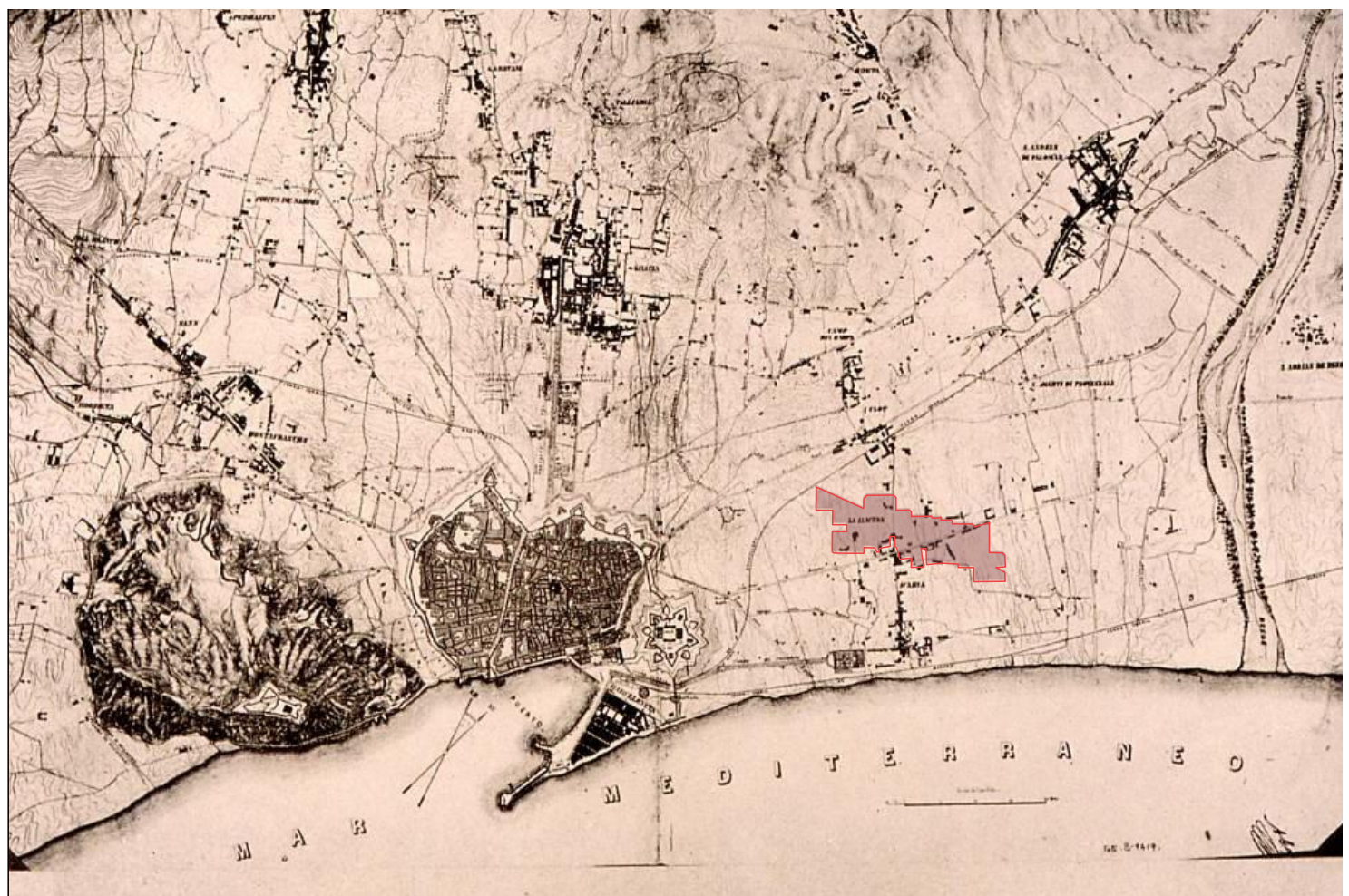

Figura 6 - Plano topográfico de Cerdà, 1855. Quando Sant Martin passou a fazer parte do município de Barcelona, seus principais eixos estruturais eram a rua de Sant Joan de Malta, ligando o bairro com às praias, e a atual rua Pedro IV, principal via de ligação do bairro ao centro da cidade. Ao se executar a rua Pedro IV, ela é construída de forma elevada, para evitar os pântanos de ambos os lados, que terminam de ser drenados ao longo do século XVIII, e atraem numerosas construções. Fonte: Instituto Cartográfico de Catalunha.

O surgimento do cemitério de Poble Nou, no início do século XIX, e fundamentalmente do passeio que conduz a Barcelona tornam-se outros dois elementos importantes para a ativação deste território, que pouco a pouco impulsionaram novas construções e a implantação de muitas indústrias.

As posteriores linhas ferroviárias, que podem ser observadas na Figura 6, acabaram por determinar o caráter industrial do lugar, isolando-o, apesar de sua posição relativamente próxima ao centro da cidade. Os trilhos do trem a Mataró, ao longo da costa (1848) e no interior do território (1853-1880), rodeiam completamente o município de Sant Martin e desenham barreiras difíceis de transpor para conectar com Barcelona e o resto dos núcleos da planície.

No plano topográfico de Cerdà se pode observar o conjunto de núcleos suburbanos ao redor da cidade de Barcelona (Figura 6), situados a uma distância do disparo de uma bala de canhão das muralhas. Entre os núcleos relativamente consolidados encontramos o Camp del Arpa, el Clot, la Llacuna e Icaria. Ainda assim, podemos reconhecer as recentes instalações e talheres ferroviários; a estrada de França; os córregos, quedas d'água e o canal; o rico mosaico de parcelamento de terras e uma estrutura radial de caminhos.

Aceleradas fortemente pela construção da ferrovia, não demoram a ocorrer importantes mudanças no limite municipal de Sant Martin. Nos mapas do último quarto do século XIX, se observa como este âmbito se transforma e ignora a margem do projeto Ensanche ${ }^{10}$. Os edifícios se elevam tomando como referência a parcela agrícola irregular e os caminhos tradicionais que Cerdà ignorou ao produzir o plano. A tecelagem artesanal se espalha pelo território e pouco depois também as fábricas. No fim do século XIX, Poble Nou passou a concentrar a maior parte das instalações industriais têxteis de algodão da Espanha. A

${ }^{10}$ A tradução em português de ensanche é expansão, e é o nome dado ao projeto urbano de Cerdà para expandir Barcelona. 
antiga paisagem, com campos de cultivos e moinhos, se converte progressivamente em imagens de chaminés e edificações industriais.

0 contraste entre o parcelamento irregular de origem medieval e o modelo ortogonal de Cerdà (Figuras 7 e 8) supõe uma dificuldade a mais nas transformações urbanas enfrentadas no fim do século $\mathrm{XX}$, mas mesmo assim, o traçado medieval também suscitava valores históricos que poderiam ser considerados no projeto Poble Nou. Lentamente, desde meados do século XIX, a cartografia demonstra que se elevam algumas peças residenciais ajustadas ao projeto urbano de Cerdà, entretanto, a maior parte, em especial as grandes fábricas têxteis, se assentam ao longo da estrada da França (Rua Pedro IV) e dos caminhos que conduzem a ela.

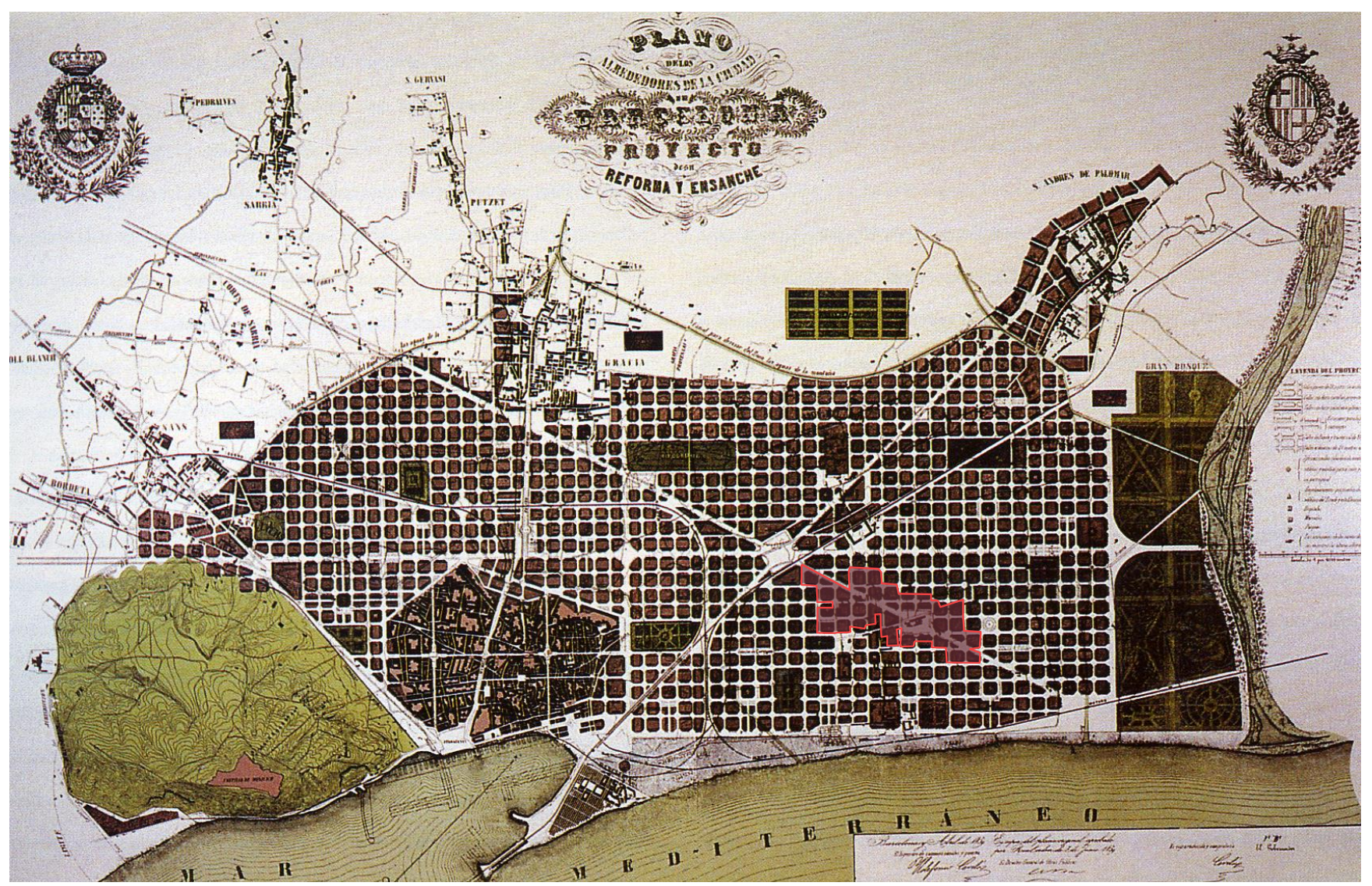

Figura 7 - Projeto de Cerdà, 1859. Fonte: Instituto Cartográfico de Catalunha. 


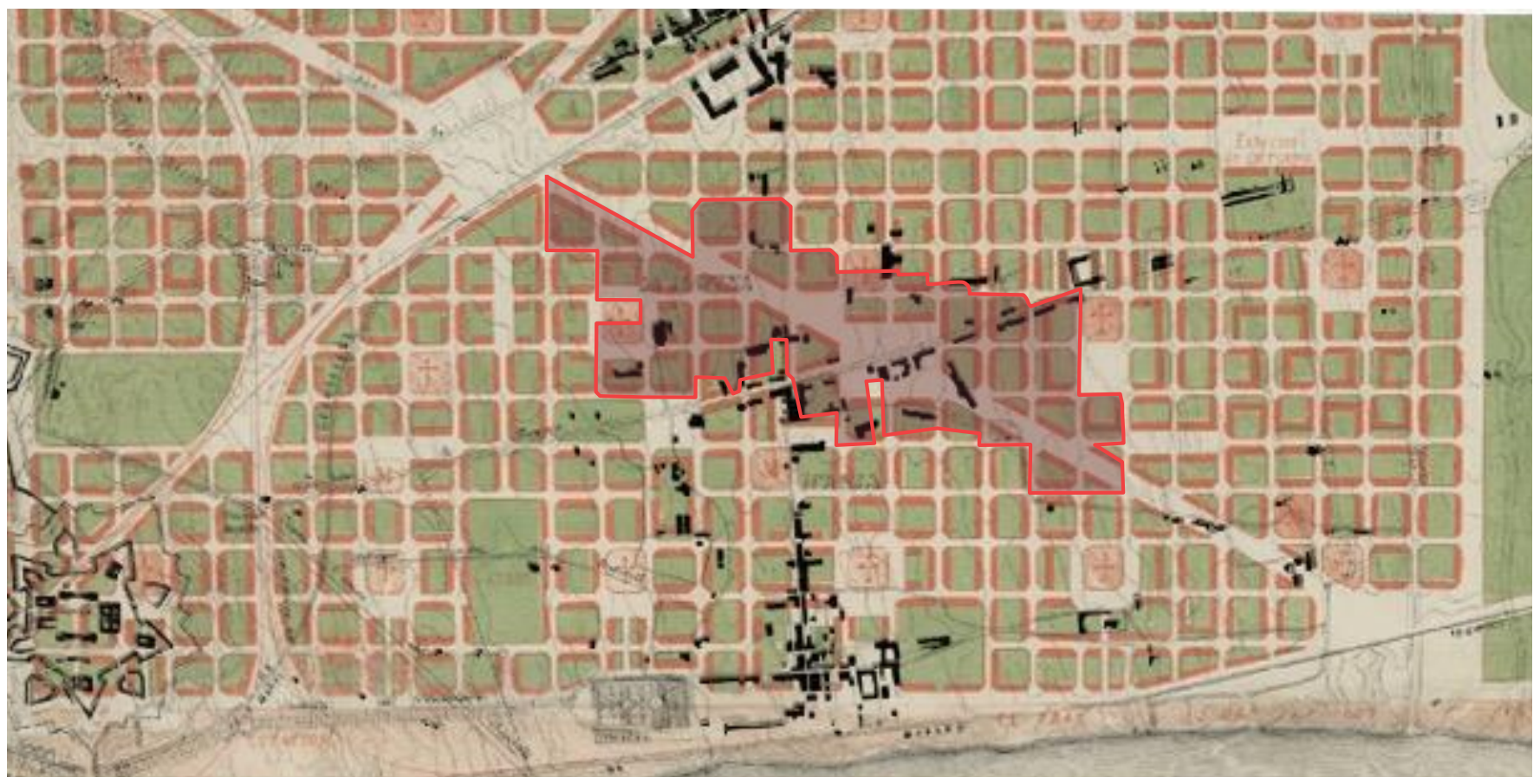

Figura 8 - Projeto de Cerdà, 1859. Enquanto Barcelona avança pacientemente com o projeto de Ensanche, Sant Martin parece viver de costas para isso. Quando a malha ortogonal alcança a Praça das Glories, aquelas tramas suburbanas consolidam seu tecido irregular e frequentemente, à margem das previsões oficiais, dobram pequenas ruas ao redor dos eixos tradicionais, com extensões menores que consolidam caminhos tradicionais e fazem surgir pequenas praças e equipamentos singulares (prefeitura, mercado e outros). As duas linhas férreas à França e a nova linha sobre a avenida Meridiana contribuem ainda mais para reforçar seu isolamento. Fonte: Instituto Cartográfico de Catalunha.

Nas figuras 9 e 10, desenhamos as parcelas e construções de 1881 e 1929 no mapa atual.

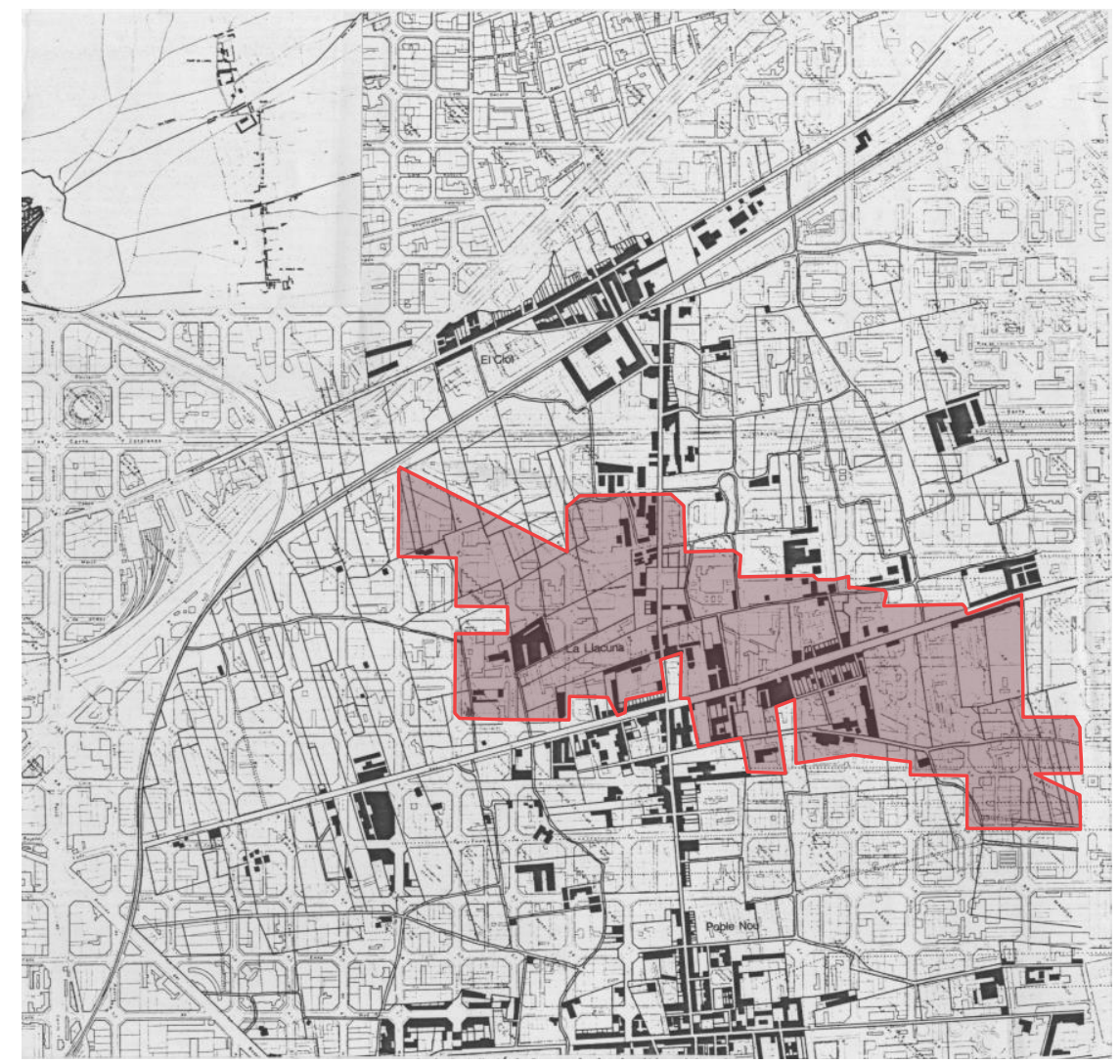

Figura 9 - Ocupação em 1881. Fonte: Elaboração própria. 


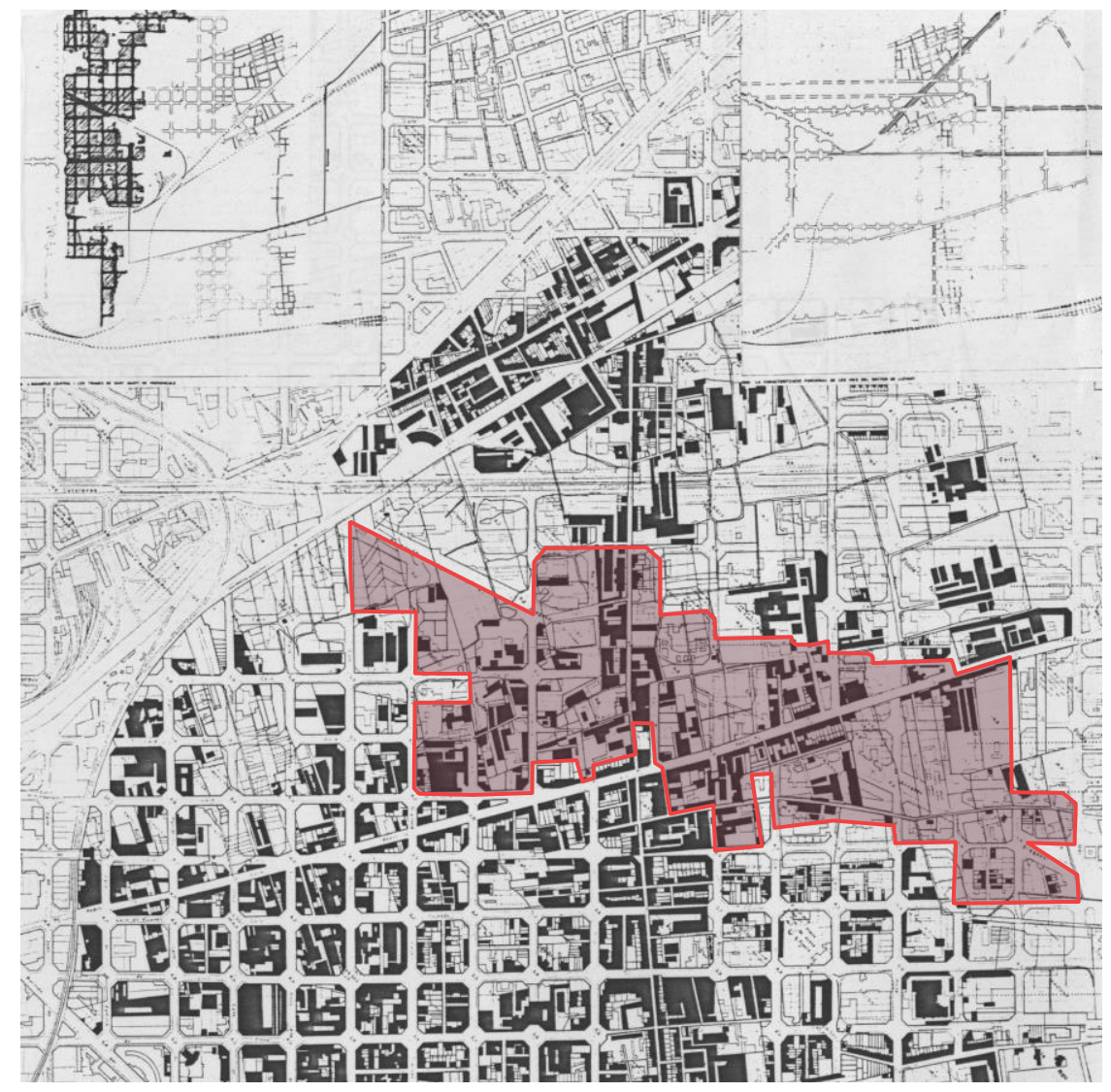

Figura 10 - Ocupação em 1929. Fonte: Elaboração própria.

O velho município se anexa a Barcelona em 1897, ainda que resulte difícil corrigir sua desconexão com o restante dos núcleos da planície de Barcelona. Apenas duas vias atravessam as linhas ferroviárias, mantendo durante cem anos uma relação umbilical com a cidade central.

Ao longo do primeiro terço do século XX, novas ruas ortogonais são abertas, ainda que a ampliação de muitas plantas industriais existentes tenha impedido sua continuidade. Todavia novas fábricas, de tamanho menor e atividade muito mais diversificada encaminham-se para respeitar a ordem ortogonal. Além disso, o tecido se complementa com construções residenciais. Fiéis às suas origens suburbanas, muitas das grandes quadras se fragmentaram e surgiram pequenas passagens, às vezes apoiadas na rede de caminhos tradicionais, com fileiras de casas em meio aos cultivos, edificações industriais e armazéns. Esta condição fragmentada e de pouca acessibilidade é resolvida quando se abre uma rua que enlaça finalmente ambos os lados do Ensanche, cruzando a Avenida Meridiana através das ruas Mallorca e Valência.

No plano Regional de 1953 a área do Poble Nou fica quase que totalmente qualificada como zona industrial, exceto o entorno de San Juan de Malta e da Avenida Diagonal.

As mudanças que ocorrem nas décadas seguintes tendem a favorecer grandes ligações viárias e completar a estrutura do Projeto Ensanche. Por volta de 1960 a 1970 se urbanizam a Avenida Meridiana e a Gran Vía, criando grandes eixos de acesso a Barcelona e soterrando a via férrea. Pouco tempo depois, com a construção da Vila Olímpica, se enterra o restante do traçado ferroviário. Tudo isso contribui para que o distrito de Sant Martin, por sua posição e urbanização, adquira a feição de cidade central. A única coisa que falta para a integração completa de Poble Nou é o prolongamento da Diagonal até o mar, e terminar a abertura de muitas ruas, previstas quase um século antes por Cerdà, ainda que, para isso, seja necessário atravessar uma zona relativamente densa e complexa. 


\section{Uma superposição complexa de tramas e a resistência à transformação (forma e dinâmicas)}

Na década de oitenta, o Poble Nou apresenta uma paisagem congestionada por plantas industriais e chaminés, depósitos e fileiras de construções residenciais, que ao longo do tempo se ajustaram às pautas do Ensanche (Figura 11). Mas a irregularidade do parcelamento rural ainda permanece marcante na paisagem e algumas grandes plantas industriais impedem o curso de numerosas vias. Se a camisa de força dos traçados ferroviários congelara alguns terrenos centrais na cidade, as novas obras de urbanização sinalizam a oportunidade de uma remodelação obrigatória. As recentes aberturas e a desaparição do obstáculo ferroviário rompem o isolamento secular com a cidade central. O Poble Nou começa de fato a ganhar centralidade e oferece o último grande solar para o crescimento de Barcelona. Sem dúvida, a abertura da Avenida Diagonal até o mar supôs um notável indutor de revitalização urbana.

E o que encontramos se sobrevoarmos essa avenida?

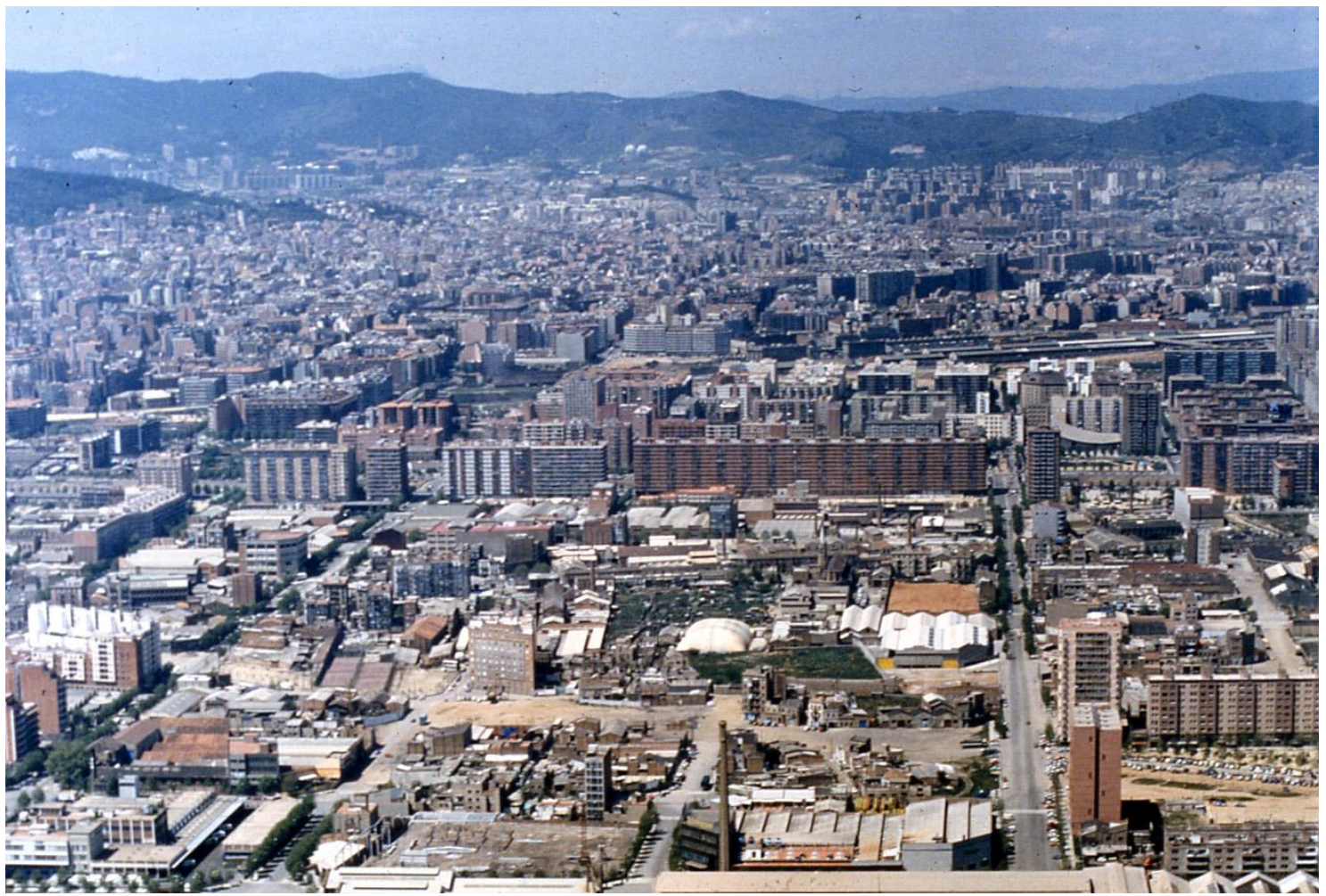

Figura 11 - Vista aérea do final da avenida Diagonal no ano de 1986. Fonte: CCRS Arquitetos (1986).

$\mathrm{Na}$ área do Plano era possível observar grandes edificações residenciais que confiaram na ordem de Cerdà e se levantam isoladas, sobretudo na fachada setentrional da avenida (Figura 12). Caracterizam-se por seu notável tamanho e altura, altivas em meio a plantas e campos de cultivo, com um acesso garantido apenas por irregulares caminhos de terra.

Também distinguimos muitas frentes residenciais, ou pequenas edificações remanescentes ao longo dos eixos tradicionais, ou encaixadas no velho parcelamento agrícola; além de fileiras de casas suburbanas, outras inseridas em paisagens isoladas e ainda muitas habitações irregulares.

Nas áreas industriais encontramos muitas fábricas fechadas; de bela feição e notável valor histórico; aguardando uma política de salvaguarda, evitando a destruição indiscriminada que supôs a construção da Vila Olímpica (Figura 13).

Mas se observam outras edificações de escasso valor, utilizadas apenas como depósitos, estratégicas por sua posição no coração da área metropolitana (Figura 14). Em outras situações, os remanescentes eram apenas lotes mal definidos, que serviram para atividades diversas (Figura 15). 


\section{O Plano Especial Diagonal-Poble Nou}
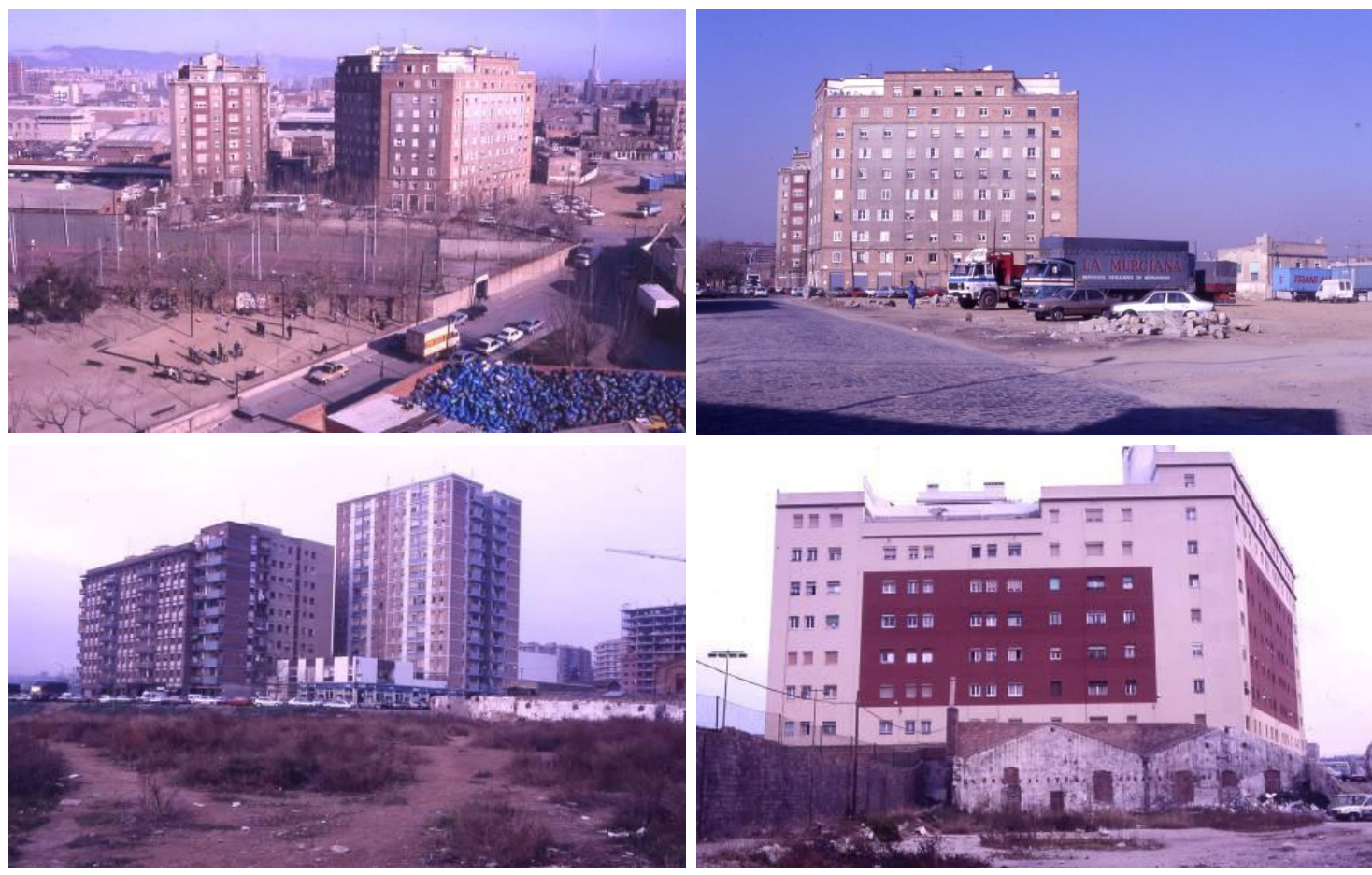

Figura 12 - Vistas do bairro Poble Nou em 1986. Fonte: CCRS Arquitetos (1986).
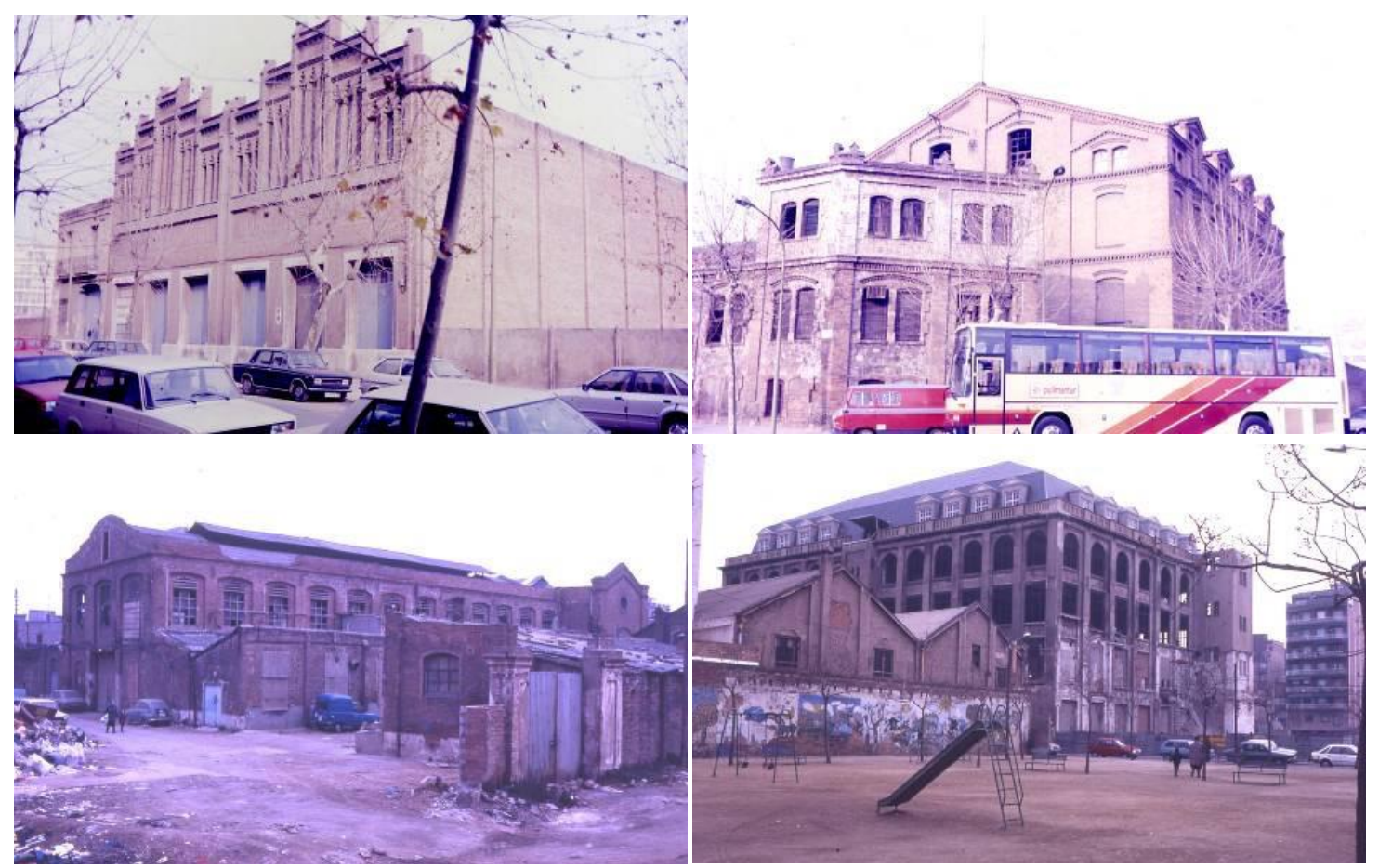

Figura 13 - Vistas do bairro Poble Nou em 1986. Fonte: CCRS Arquitetos (1986). 


\section{O Plano Especial Diagonal-Poble Nou}
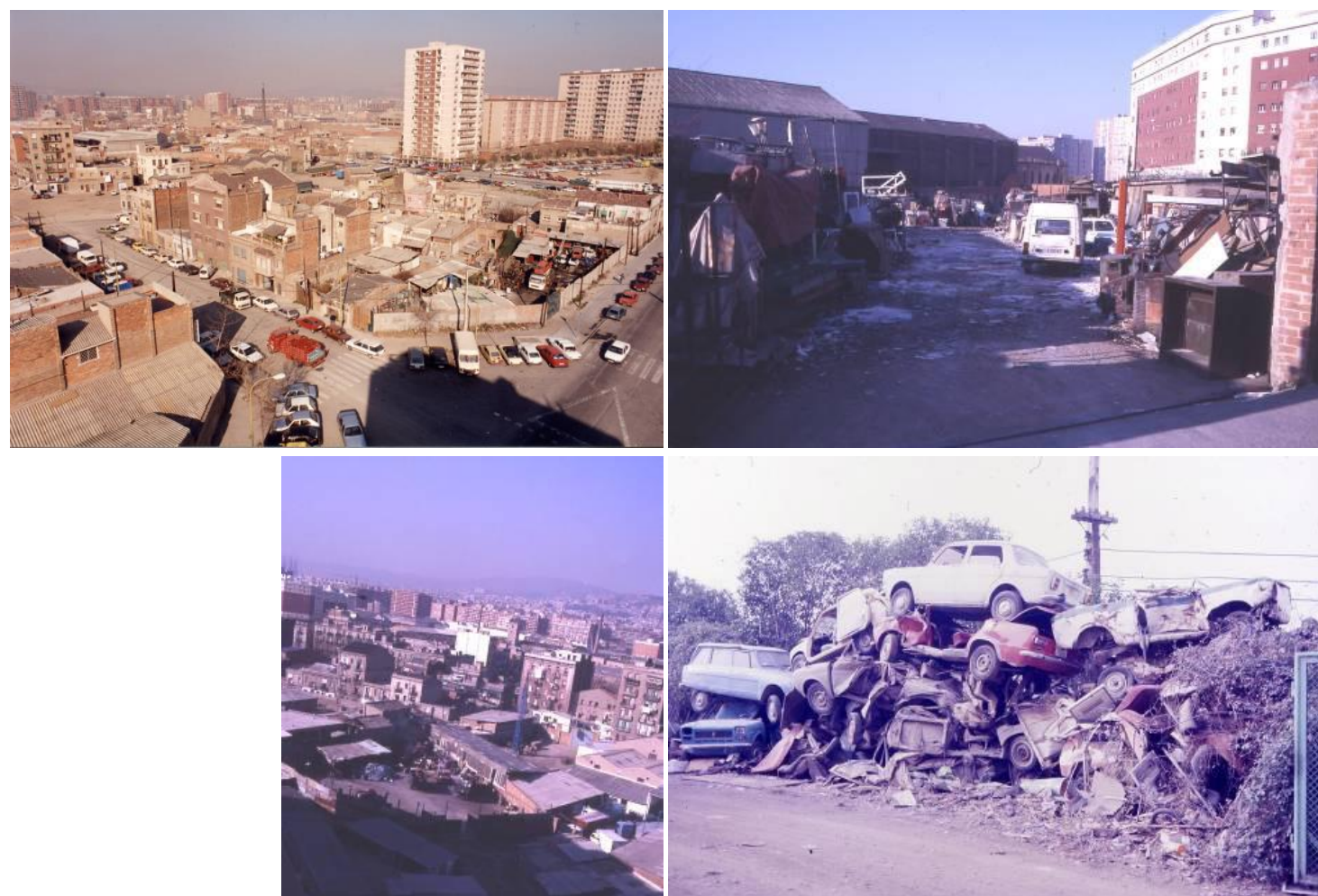

Figura 14 - Vistas do bairro Poble Nou em 1986. Fonte: CCRS Arquitetos (1986).
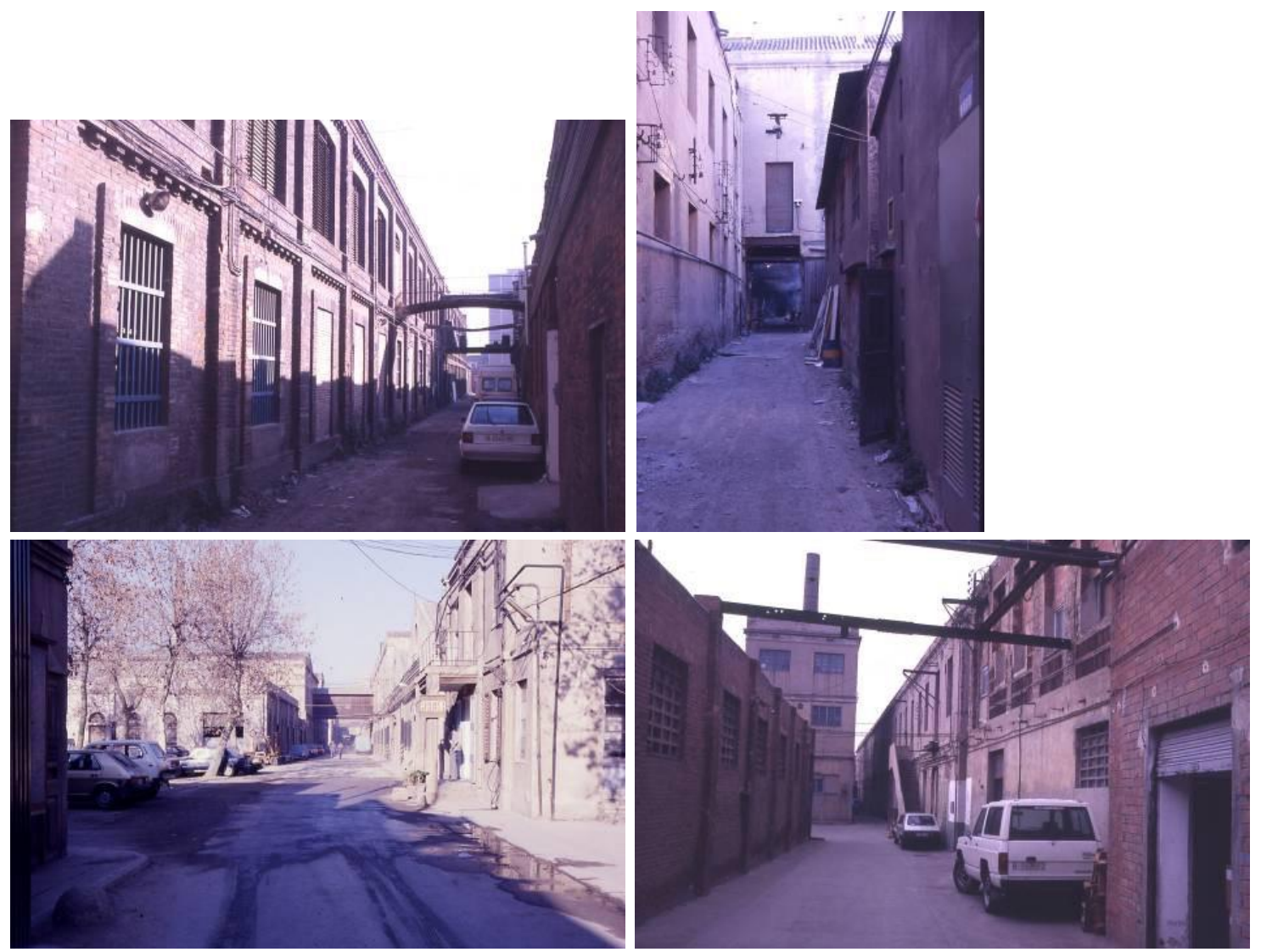

Figura 15 - Vistas do bairro Poble Nou em 1986. Fonte: CCRS Arquitetos (1986). 

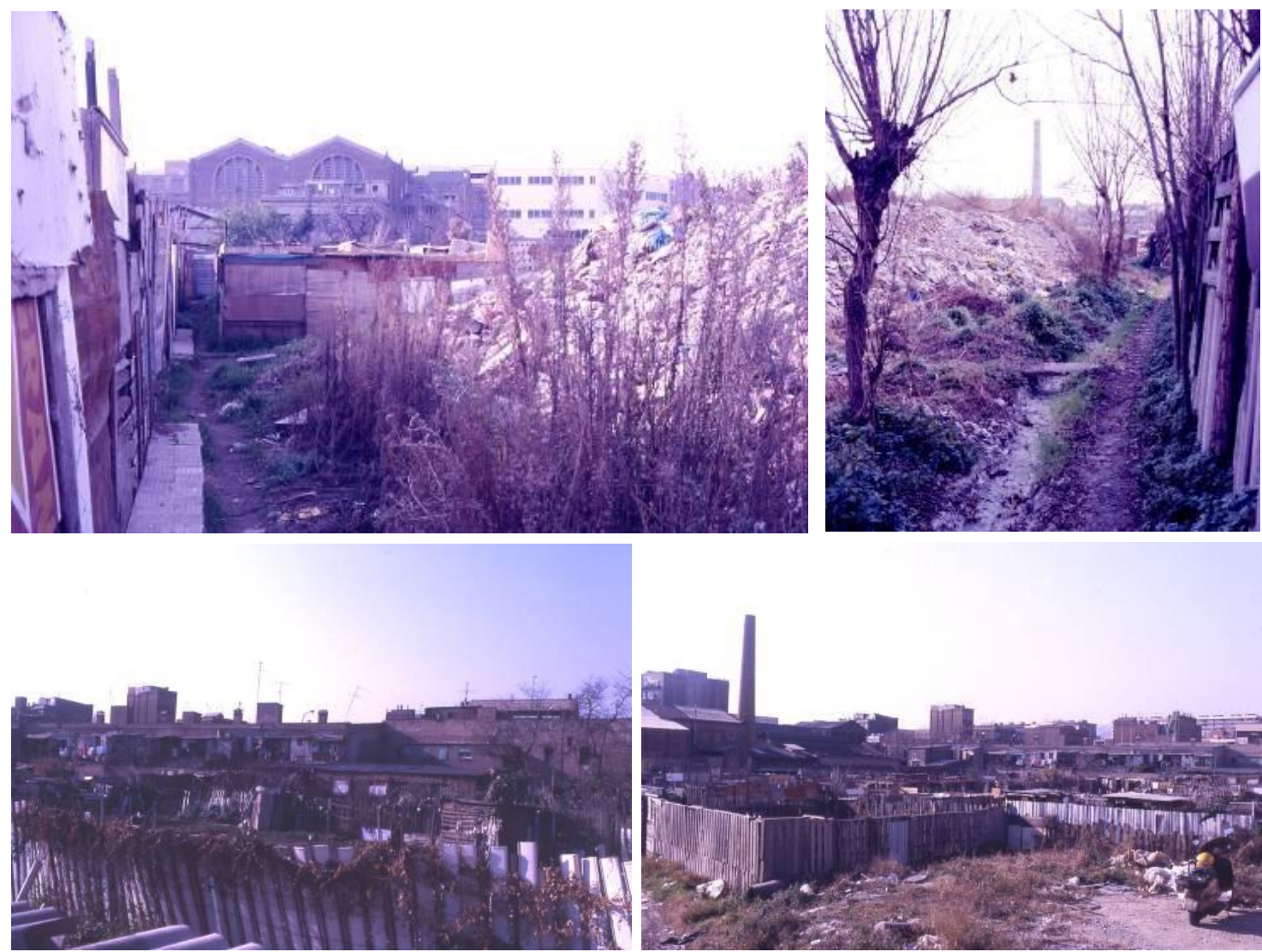

Figura 16 - Vistas do bairro Poble Nou em 1986. Fonte: CCRS Arquitetos (1986).

As grandes empresas haviam fechado suas portas há algum tempo, ou se transferido, e muitas aguardavam o incremento dos preços da terra pela transformação anunciada. Muitas daquelas plantas foram subdivididas e novamente alugadas, e se encontravam ocupadas por pequenas e numerosas atividades, muitas vezes frágeis e ilegais, com uma vida útil de dois ou três anos ${ }^{11}$.

Inclusive os terrenos que no projeto do Ensanche se reservaram para a abertura da avenida ou a construção de algum parque, para os quais não se concede permissões de edificação, foram ocupados por construções provisórias, campos de futebol ou hortas agrícolas (Figura 16).

Se a futura transformação deste território reclamava um adequado tratamento das tramas históricas, as características dos tecidos exigiram uma atenção especial. A análise do rico mosaico de parcelamento oferecia pautas bem interessantes para avaliar as futuras intervenções. Havia em torno de 600 propriedades com uma superfície média de quase mil metros quadrados, o que permitia imaginar um alto nível de agregação e garantia de uma execução ágil e facilitada. Mas isto não devia induzir a equívocos, pois a maior parte das parcelas eram de tamanho bem reduzido e a divisão cadastral não era em absoluto homogênea, existiram áreas com um mosaico muito fragmentado (aquelas de conformação mais tradicional) e outras onde apenas aproximadamente $10 \%$ dos proprietários detêm a metade do solo ${ }^{12}$.

Durante alguns anos era possível apreciar um movimento de compra e venda de terrenos, afetados no planeamento vigente por ruas e espaços públicos, em um processo se que acelera com as expectativas de transformação e suposto ganhos de capital (mais-valia) que uma esperada equidade na distribuição de direitos conferia.

11 Dados de acordo com uma pesquisa morfológica detalhada que realizamos em todas as atividades existentes.

${ }^{12}$ Analisamos individualmente todas as características detalhadas de todas as parcelas, proprietários e construções. 
Outro documento produz uma análise do interesse das edificações, época de construção, nível de conservação ou relação entre o edificado e uso (Figura 17). Junto a edifícios de um notável valor descobrimos uma grande maioria de construções obsoletas.
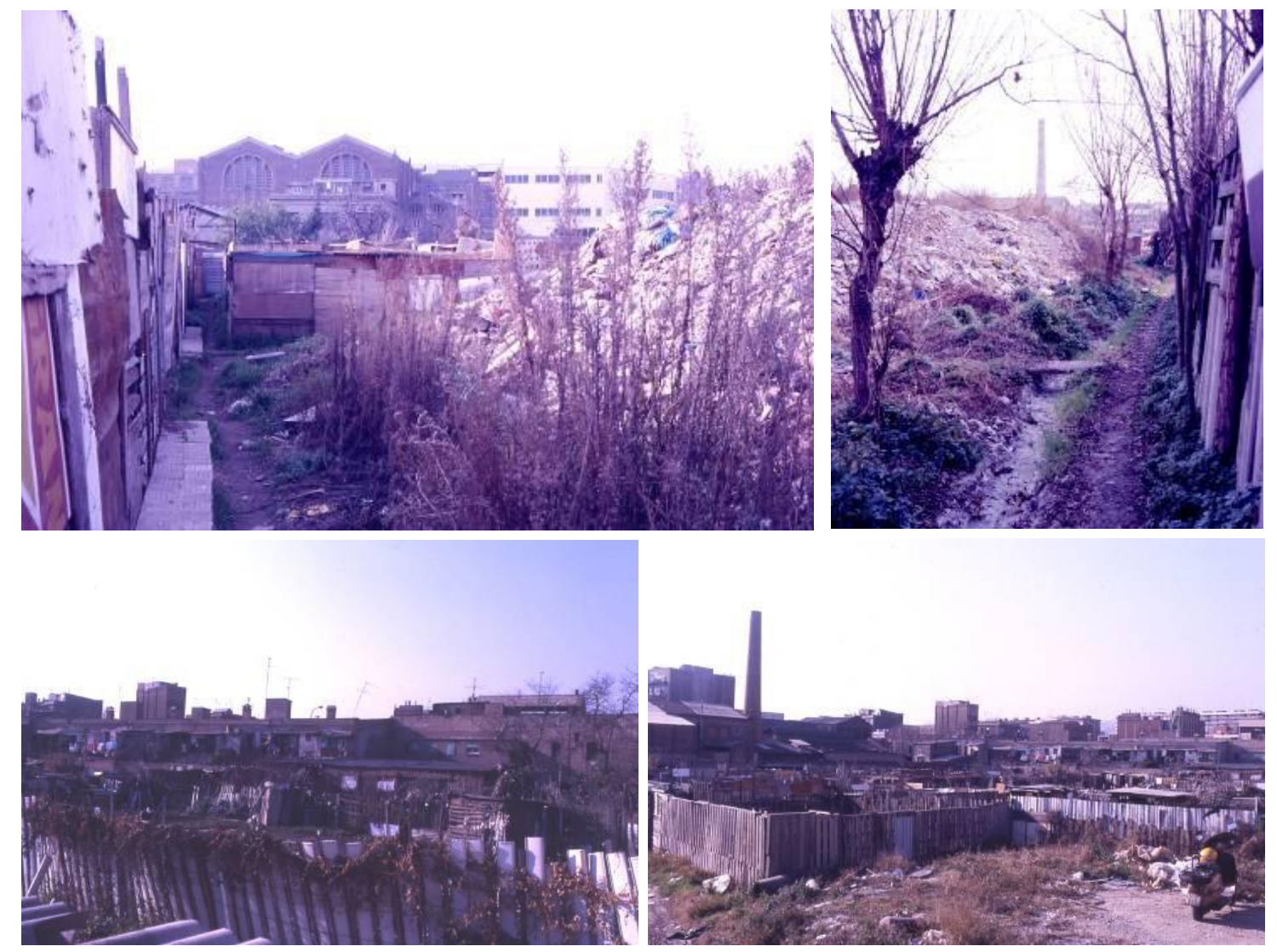

Figura 17 - Estado das construções, 1986. Fonte: CCRS Arquitetos (1986).

Um reconhecimento extenso sobre o terreno e uma pesquisa detalhada de todas as parcelas, proprietários, atividades e construções nos permite, por sua vez, conhecer detalhadamente as características de mais de 500 atividades não residenciais, caracterizadas por seu vertiginoso ritmo de desaparecimento. A cada dois anos, um terço das propriedades compartilhadas muda de uso, e, em uma década, o número de empresas recém-chegadas substitui quase totalmente as existentes. Predominava uma mescla de indústrias de médio porte e depósitos, com pequenos bolsões residenciais. Mas, de modo geral, a maior parte das atividades econômicas se caracteriza por sua marginalidade, sem licenças nem possibilidade de obtê-las, com numerosos trabalhadores não registrados, em instalações urbanisticamente afetadas por mais de um século de uso. Este reconhecimento minucioso também permite distinguir uma rica diversidade de áreas homogêneas (complexos unitários, recintos subdivididos, oficinas, instalações em desuso, entre industriais e residenciais, habitações do tipo sobrados e blocos multifamiliares). Por sua vez, isso dá lugar a outros estudos bem originais, como medir a capacidade de transformação dos diferentes remanescentes arquitetônicos, a partir da vontade de manter o caráter misto do bairro. 


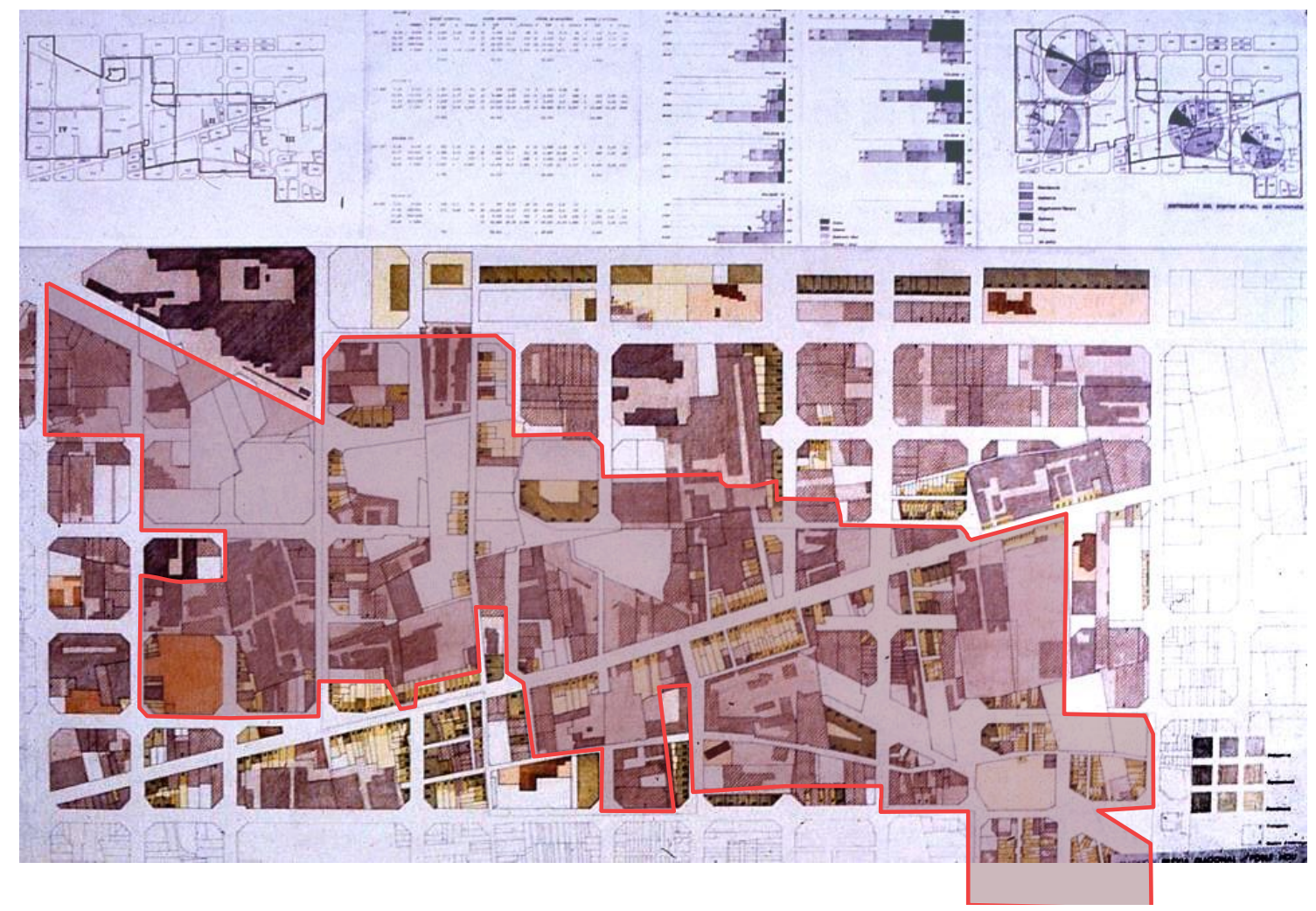

Figura 18 - Resistência a mudança. Fonte: CCRS Arquitetos (1986).

O projeto avalia com precisão a resistência de cada uma das atividades à futura transformação, seja ela qual for. Calculam-se os custos de transferência em função da relação entre edifício e atividade; de seu grau de mecanização e número de trabalhadores; de sua posição e nível de agrupação; das características físicas do edifício; dos vínculos contratuais; de possíveis economias de todo tipo (de escala, posição, urbanização); do enraizamento da atividade (Figura 18).

Sem dúvida todos estes estudos reforçam a pretensão de dispensar especial atenção à manutenção do estreito vínculo entre atividades de pequena indústria e atividades residenciais. Com ele se pretende assegurar uma certa continuidade do tecido social e do caráter tradicional do bairro de Poble Nou.

\section{As apostas do Plano Especial Diagonal-Poble Nou (espaço público e população)}

O Plano Especial Diagonal-Poble Nou enunciava três objetivos fundamentais, compartilhados tanto pela equipe redatora quanto pelo poder público municipal:

1. Continuar a Avenida Diagonal até o mar, completando uma extensão de 10 quilômetros ao longo da cidade, consolidando um foco de atividades num eixo transversal que confere centralidade e revitaliza um bairro degradado, evitando um efeito barreira.

2. A questão mais importante é a remodelação do tecido atravessado, e isso implicava:

Completar a malha de ruas ortogonais do bairro, que o torne permeável e restabeleça vínculos com a cidade central.

a) Desenhar um tecido residencial com suficiente extensão (6.000 unidades residenciais novas) e equipamentos públicos adequados para as demandas existentes e futuras.

b) Aproveitar a extensa área de propriedade pública municipal ou os direitos como administração atuante para conseguir que ao menos um terço desse total se destinasse a habitação social, para favorecer a realocação de residentes sem o deslocamento da população local para áreas distantes da cidade. 
c) Manter, no que seja possível, os traçados e elementos de interesse identitários preexistentes, reutilizando-os como equipamentos públicos, ou reconhecendo-os dentro da trama de espaços livres.

3. Em terceiro lugar, se propôs ordenar e garantir condições de coexistência das residências e atividades produtivas, tentando preservar as pequenas indústrias para conferir uso misto ao bairro, e buscar modelos de compatibilidade entre usos.

No impulso da operação de remodelação de finais dos anos oitenta coube reconhecer incrementos de oportunidades, para aproveitar o avanço urbanístico de Barcelona e as obras de urbanização olímpicas, sendo estes o desaparecimento da linha ferroviária, a abertura da cidade ao mar e a construção da Vila Olímpica, a fim de responder a uma crescente demanda residencial e rentabilizar importantes inversões públicas.

Vejamos como se traduz cada um dos objetivos.

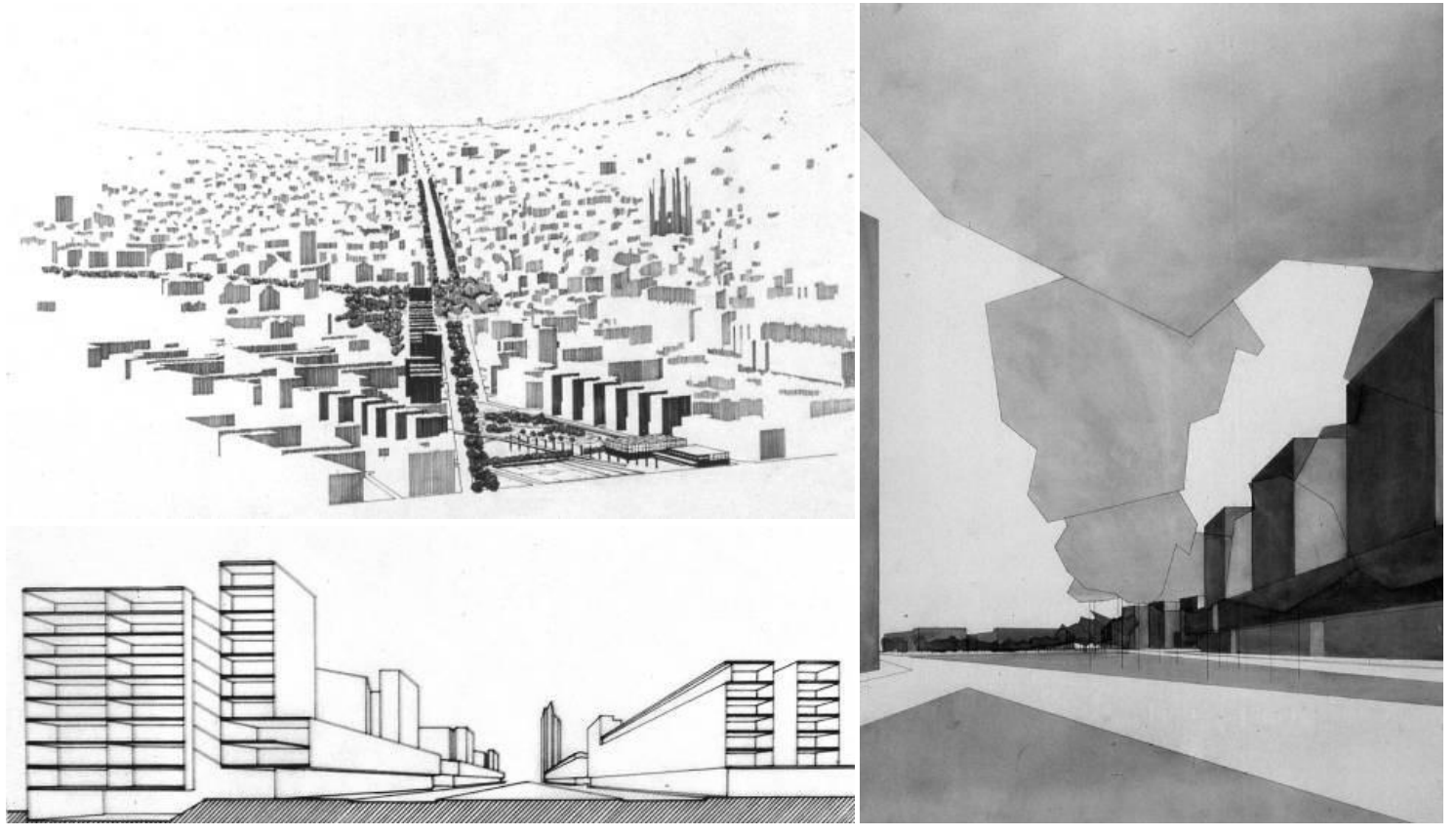

Figura 19 - Imagens do projeto. Fonte: CCRS Arquitetos (1986).

Ao longo da cidade consolidada a Avenida Diagonal apresenta seções diversas. Ao atravessar o Ensanche Central os alinhamentos se ajustam com rigor e apresentam fachadas relativamente homogêneas e contínuas de sete andares, com poucas exceções (edifícios singulares que apresentam uma base de dois ou três andares e um corpo muito mais alto e recuado).

No trecho a oeste, a seção se faz muito mais generosa, alcançando 80 e até 100 metros de largura no corte transversal. A edificação alinhada e de altura uniforme se substitui por blocos isolados, com abundância de edifícios de escritórios e equipamentos.

O que fazer então no trecho desde a Praça das Glorias até o mar?

A Praça das Glorias se apresenta como um nó viário complexo. 0 traçado da Diagonal estava pontuado por alguns edifícios de tamanho considerável, alinhados em sua fachada norte e apresentando um bloco extraordinariamente longo, em forma de dente de serra. Por isso, na elaboração do Plano foram propostos dois modelos alternativos a esta conformação, ambos defendendo continuidade da fachada edificada (Figuras 19 e 20). 0 primeiro segue as pautas tradicionais do Ensanche, o segundo confia a continuidade a um embasamento de três andares sobre o qual se pode sobrepor volumes de formas diversas, ainda que respeitando um certo gabarito e distâncias proporcionais entre eles. 

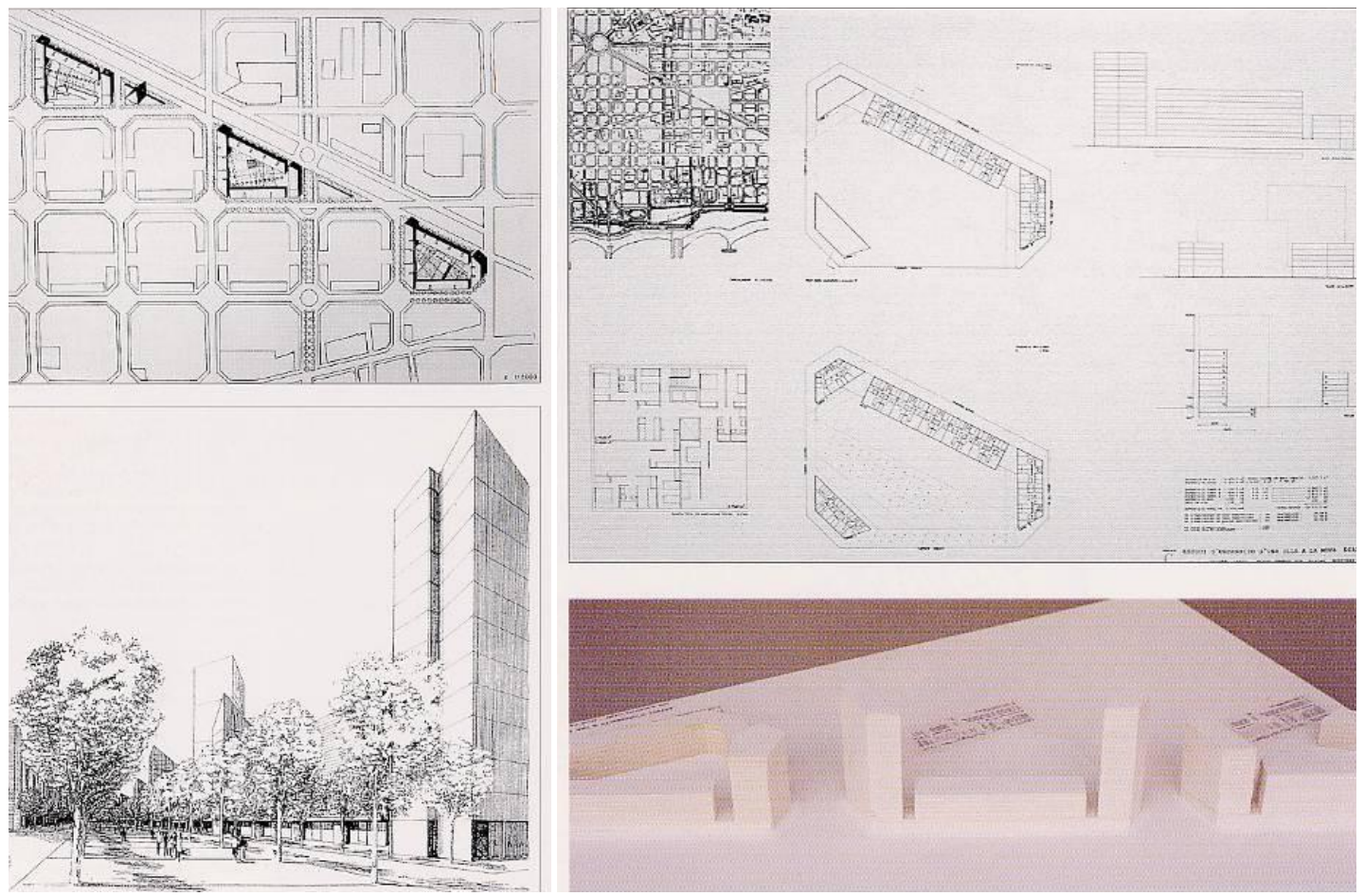

Figura 20 - Alternativas de projeto. Fonte: CCRS Arquitetos (1986).

Buscava-se uma mescla de usos diversos (comerciais em planta baixa, serviços e escritórios na base, com habitação em cima), uma imagem arquitetônica potente e característica na escala da cidade. Alguns edifícios singulares, nos cruzamentos ao redor de um grande Parque Central, serviam de contraponto à ordem mais geral da Avenida e às ruas do Ensanche.

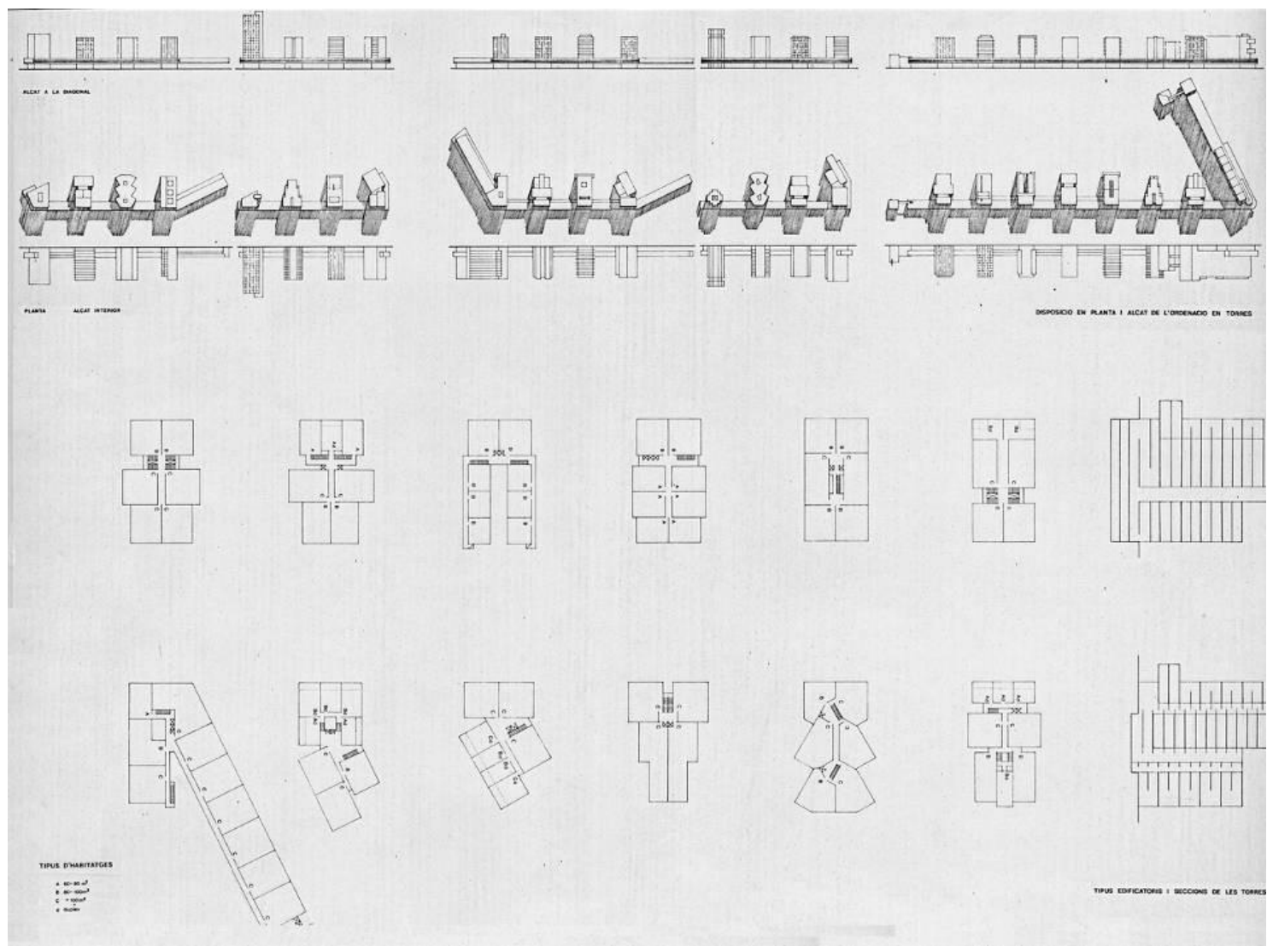

Figura 21 - Alternativas tipológicas. Fonte: CCRS Arquitetos (1986). 
Para verificar a ordenação proposta são desenvolvidos diversos programas residenciais, comerciais, ou de escritórios (Figura 21). E para garantir a requalificação do tecido que permanece de costas para a avenida, buscando maior permeabilidade física e visual possível, se idealiza um amplo passeio para pedestres, por meio do qual se chega diretamente a equipamentos e espaços livres (Figuras 22 e 23). Ao sul deste calçamento, mantém-se a ordem da quadrícula de Cerdà com edificações alinhadas, mas sem fechar totalmente as quadras, com jardins e equipamentos nos interiores. As profundidades edificáveis são limitadas, para garantir uma adequada ventilação cruzada, e se limitam as alturas.

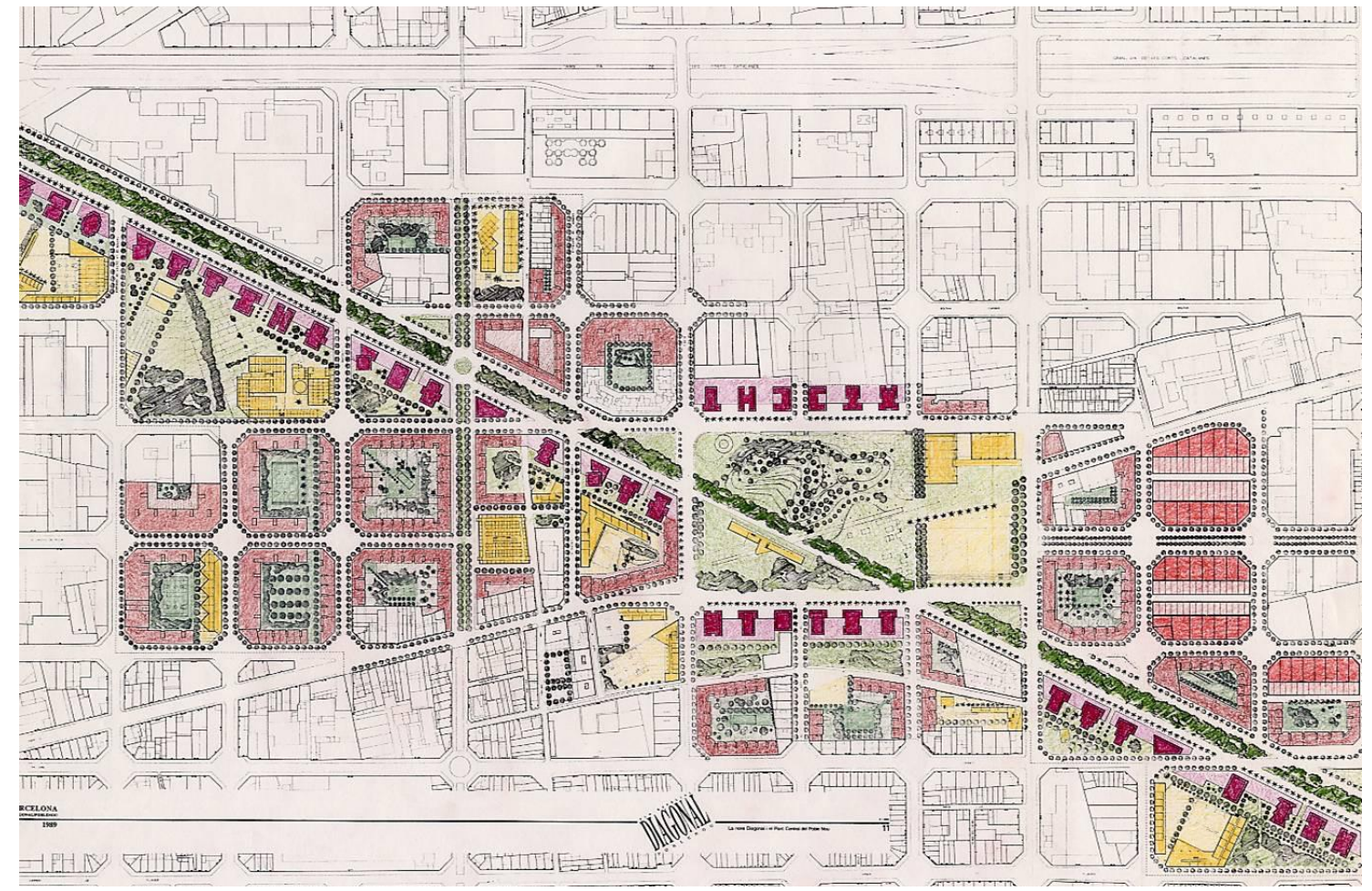

Figura 22 - Primeira proposta Diagonal-Poble Nou. Fonte: CCRS Arquitetos (1986).

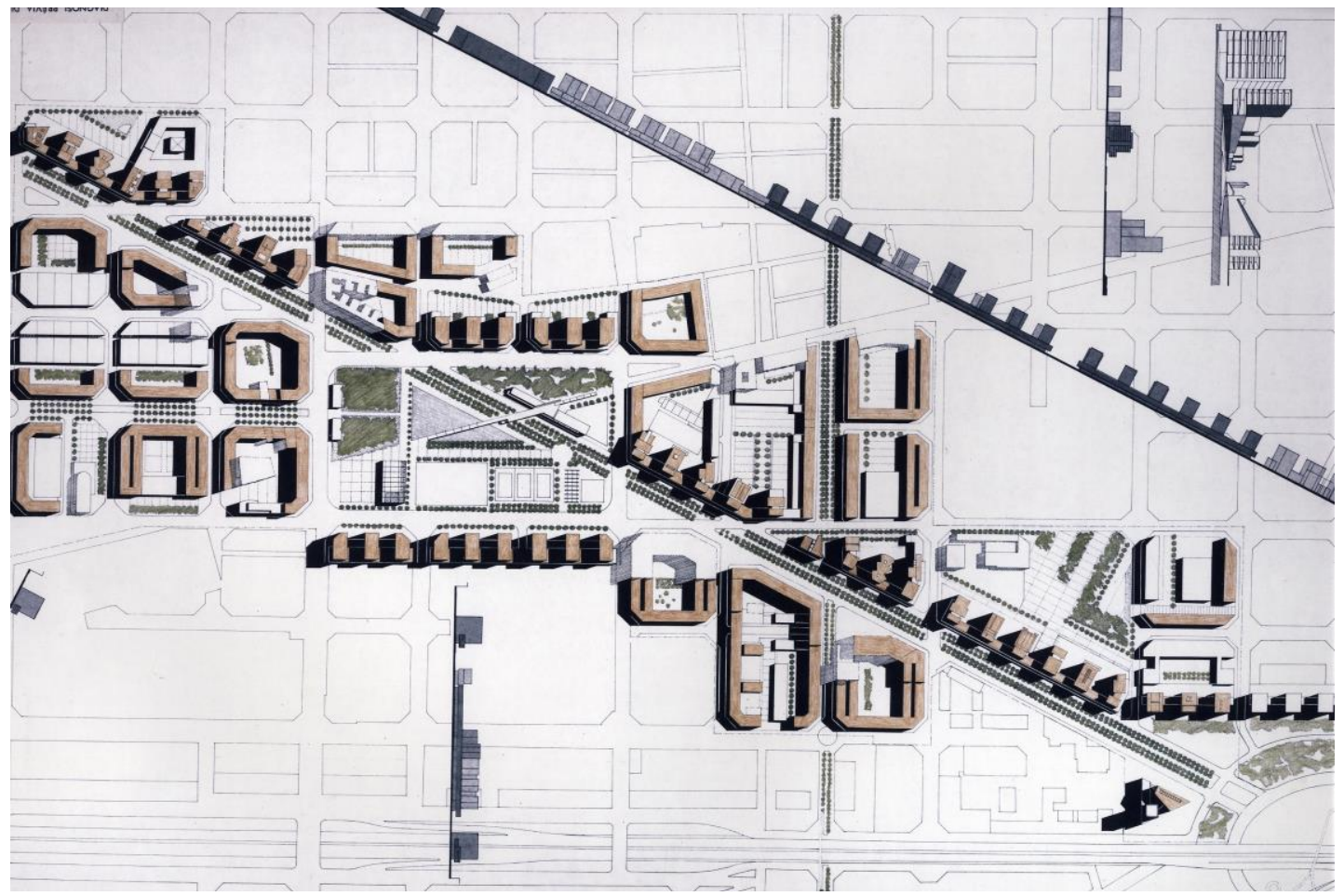

Figura 23 - Primeira proposta Diagonal-Poble Nou. Fonte: CCRS Arquitetos (1986). 
Algumas construções industriais relevantes são preservadas como equipamentos, assim como numerosos traçados pré-existentes.

Com essas medidas, pretende-se um tratamento potente e homogêneo (ainda que não unitário), visando conferir uma imagem de centralidade. Também se reconhece a singularidade da fachada norte, em parte consolidada, na qual se completam frentes alinhadas de altura comum, com alguns ajustes pontuais. A fachada sul é tratada como um pavimento permeável, com acesso a estacionamentos, núcleos de comunicação vertical, equipamentos, parques e passeios; com torres de até dez andares separadas entre si por espaços de 40 e 50 metros. Entretanto, contra o critério da equipe redatora, o poder municipal adota para a avenida uma definição supostamente contínua das frentes edificadas, rompendo as esquinas com pequenos blocos isolados mais altos.

Para manter o estreito vínculo entre as pequenas indústrias, os escritórios e as residências, propõemse modelos de quadras relativamente abertas e com usos compartilhados, ainda que precisamente localizados, concentrando as atividades da indústria e possibilitando tipologias diversas.

Os seguintes critérios foram estabelecidos para a disposição dos equipamentos públicos:

a) valorizar as necessidades no âmbito dos serviços.

b) reforçar o caráter do lugar com elementos urbanos representativos, concentrados precisamente ao longo de alguns eixos cívicos tradicionais.

c) vincular espaços livres e equipamentos buscando sinergias.

d) reaproveitar antigos edifícios de valor arquitetônico como receptáculos de equipamentos.

Quanto aos espaços livres, para além da avenida e do passeio paralelo à mesma, se propôs um encadeamento de parques (integrando a grande praça prevista em Glorias, o parque do mar ao final da Diagonal e um grande parque central de aproximadamente 10 hectares de extensão).

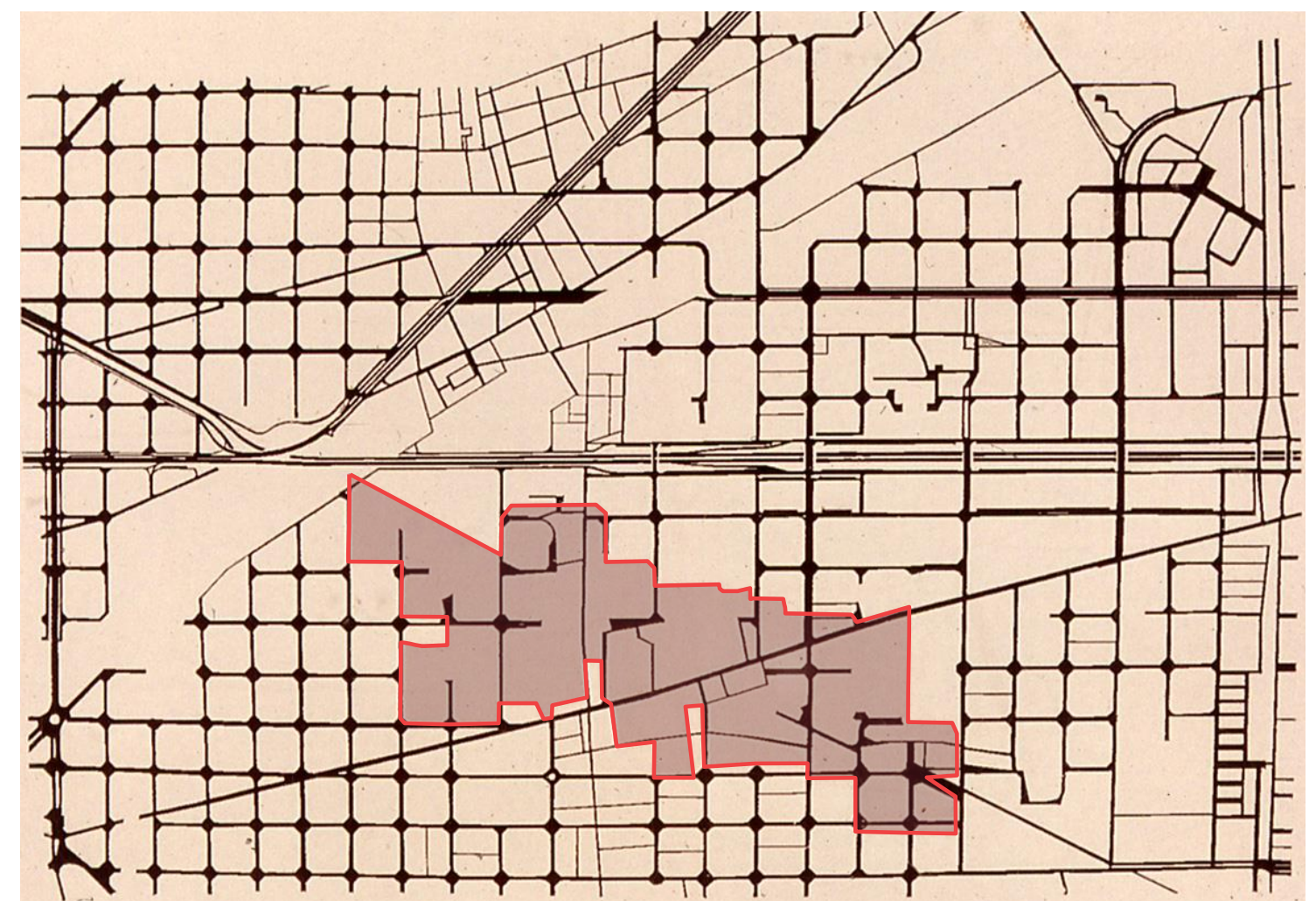

Figura 24 - Rede viária existente. Fonte: CCRS Arquitetos (1986).

Antes da implantação das propostas do Plano Especial, a imagem da rede viária existente se mostra como um gráfico incompleto, com poucos fragmentos de malha regular e outros de dimensões muito pequenas; áreas inacabadas, vias interrompidas, sem continuidade das mais importantes. Das vias horizontais, apenas duas atravessam de lado a lado. 
O Plano Metropolitano, ainda vigente, reforça em 1976 o cinturão ferroviário e agrega duas autovias urbanas com um grande nó viário na Praça das Glorias. Mas, apesar da hierarquização de certas vias, não obedece com clareza a nenhuma ordem.

Com a proposta do Plano Especial se pretende recobrar aquela ordem clara da malha de $3 \times 3$ ruas, determinada pelas pontes sobre a Gran Vía ${ }^{13}$. Também se propôs dotar de caráter cívico todas aquelas vias urbanas não imprescindíveis para o tráfico principal. Deste modo, rebaixa-se o leito de circulação do final da Diagonal, que se converte em via de passeio e eixo articulador de bairro e cidade. Além disso, o plano propõe outras rotas cívicas e mantém antigos caminhos.

Como consequência destas premissas, se conectam todas as ruas outrora interrompidas pela barreira da ferrovia, priorizando as ruas perpendiculares ao mar (Figura 24).

Que novidades oferece o Plano Especial em termos de gestão?

Depois do estudo exaustivo do custo de todas as mudanças necessárias (desde a movimentação de maquinaria; indenização de trabalhadores; lucros cessantes e tempo de interrupção da atividade; solo e construções; diferença de aluguéis; dentre outros) se estabelecem algumas premissas:

a) A operação deve ser protagonizada e estritamente pautada pela administração pública, que deve realocar famílias afetadas e atividades, preferencialmente na mesma zona.

b) Um terço do aproveitamento edificável deve ser público, destinado a favorecer a realocação e a construção de habitações de custo moderado.

c) Sabendo que existem partes muito mais resistentes que outras, divide-se o âmbito em uma vintena de unidades de atuação com aproveitamentos muito similares (Figura 25), atribuindo a cada uma delas obrigações de urbanização e alguns custos de compensação (indenizações, demolições, realocações...), tanto internos às unidades como dentro do denominado polígono zero (Figura 26). Este âmbito compreende uma franja central qualificada secularmente como viário e sistema de espaços livres e equipamentos públicos, e portanto sem aproveitamento privado. Como resultado, as obrigações e direitos de cada unidade ficam equilibradas.

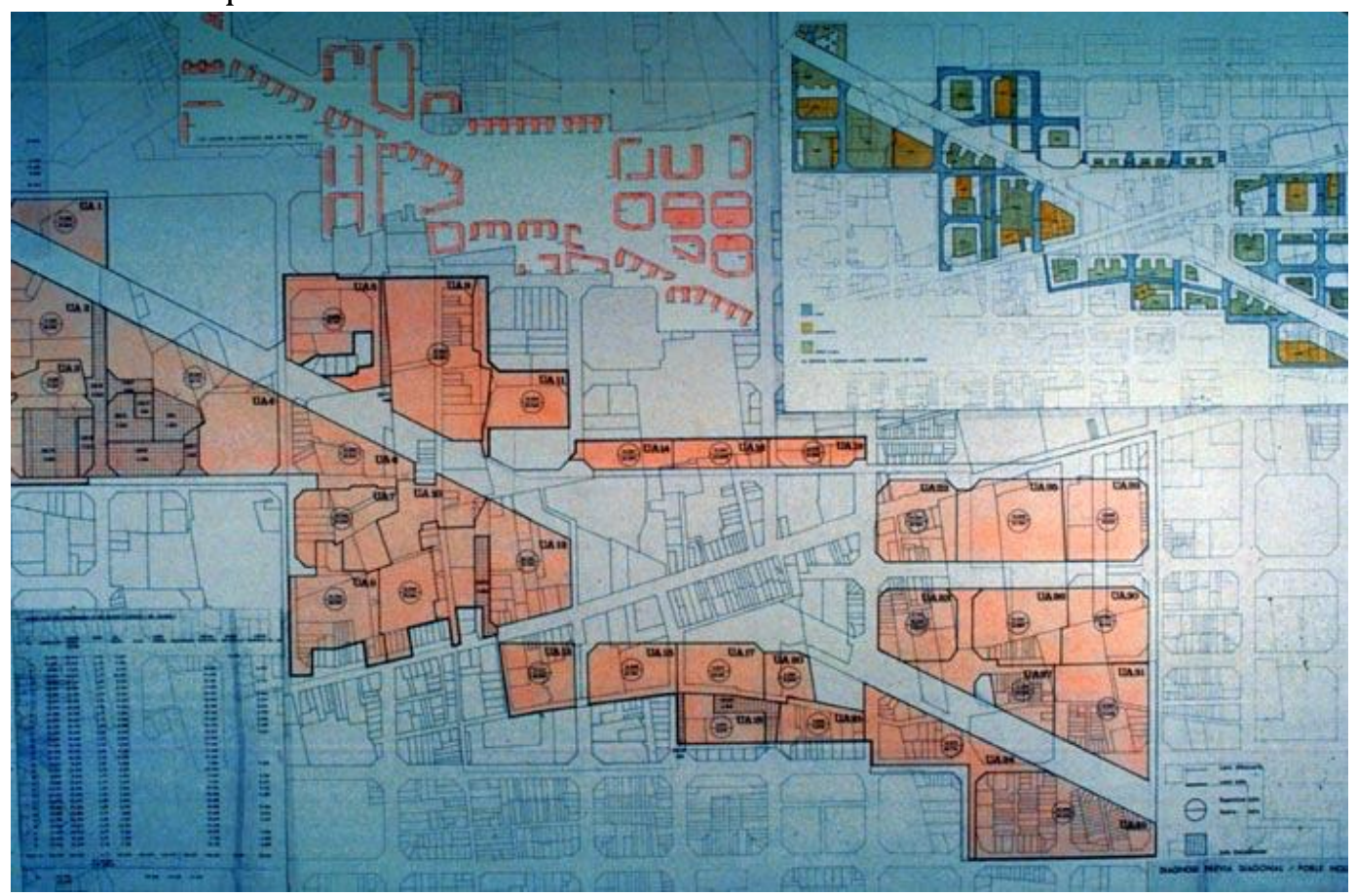

Figura 25 - Unidades da atuação. Fonte: CCRS Arquitetos (1986).

${ }^{13}$ Cerdà já propôs uma hierarquia clara a cada três ruas do Ensanche, que é respeitada ao dispor as pontes que cruzam a Gran Vía. 


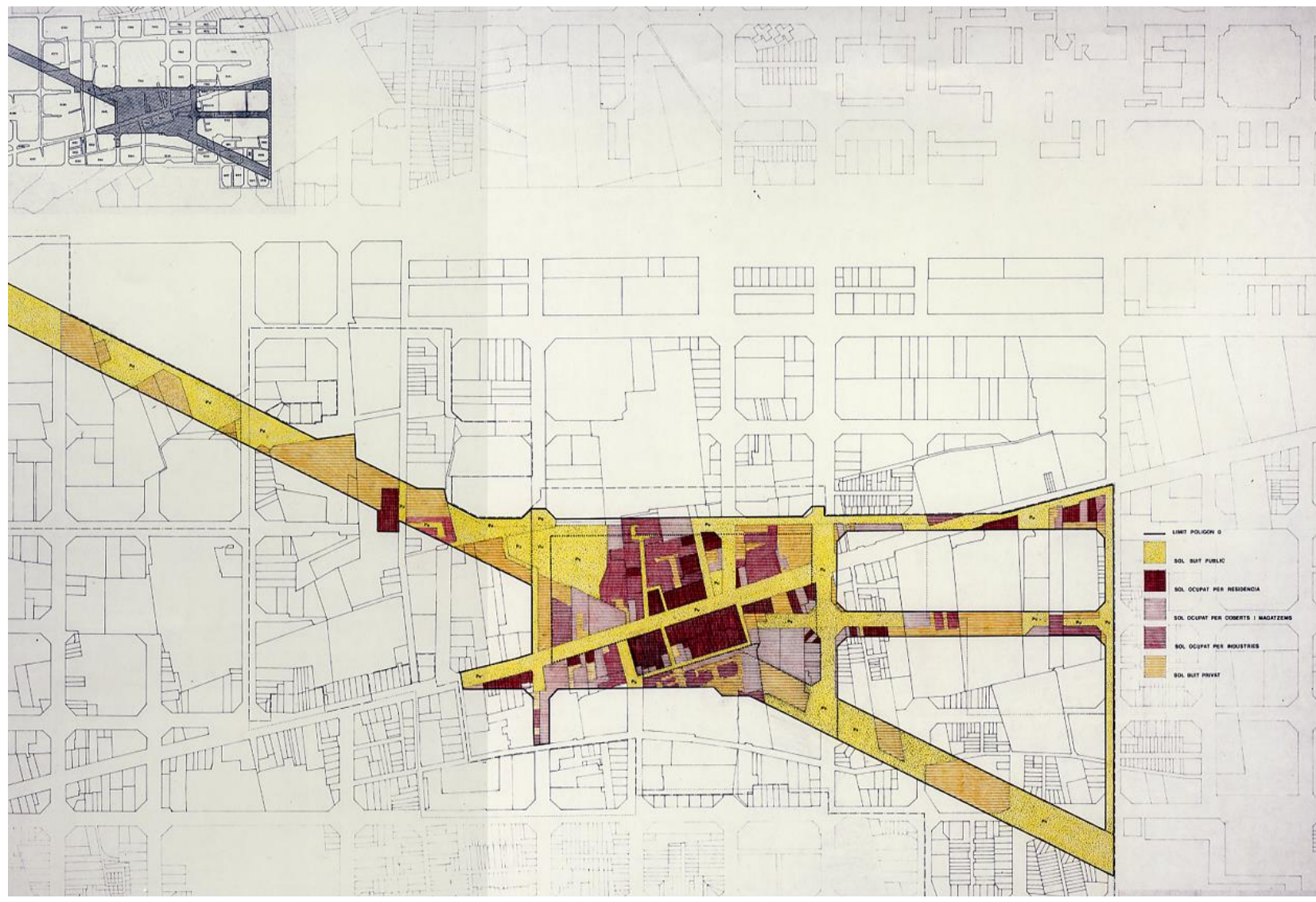

Figura 26 - Polígono zero. Fonte: CCRS Arquitetos (1986).

Existia um decreto-lei destinado a impulsionar grandes transformações de 197214. Por meio desse, propõe-se que o município inicie um processo de desapropriação do conjunto e libere unidades para atuação, à medida que os proprietários envolvidos cumpram suas obrigações e recebam seus direitos. Deste modo se assegura a viabilidade da operação, evitando desequilíbrios entre zonas ou permanecer hipotecado ao ter que enfrentar custos sobre as áreas sem aproveitamento.

\section{Crônica de um debate anunciado}

Em apenas dez anos, a avenida foi aberta e urbanizada com um grande passeio central. Se comparamos as imagens da proposta do Plano Especial Diagonal-Poble Nou com aquela finalmente aprovada e executada veremos notáveis similitudes (Figura 27 e 28) ${ }^{15}$. Os princípios do Plano Especial (continuidade + permeabilidade; ordem de Cerdà + respeito às preexistências; concluir uma malha homogênea mas hierarquizar seu uso; reequipamento + recuperação do patrimônio; memória da industrialização; estrutura de espaços livres) são amplamente mantidos, embora muitas das expectativas iniciais já se mostrassem reduzidas. Entretanto, as sutis diferenças são significativas.

Por exemplo, se restringe o tamanho do parque central; a Avenida Diagonal o atravessa completamente, e se reduz ligeiramente a proporção de espaços livres. Também se reduz radicalmente a quantidade de solo industrial. Opta-se por uma continuidade mais tradicional da fachada Sul da avenida, ainda que esta decisão acabe modificando ainda mais o tecido, porque o seu alinhamento frontal é

14 Decreto 458/1972, de 24 de fevereiro, sobre liberação de desapropriações urbanas.

15 Durante o processo de informação ao público, e a partir das sugestões de diferentes agentes, as prefeituras costumam solicitar à equipe redatora alterações na documentação antes de aprovar definitivamente o Plano. 
atravessado por ruas do traçado ortogonal que antes não passavam. Se introduz a singularidade de muitas peças de esquina ou quadras recortadas, e o desenvolvimento posterior de cada quadra se realiza com excessiva autonomia em cada estudo de caso.

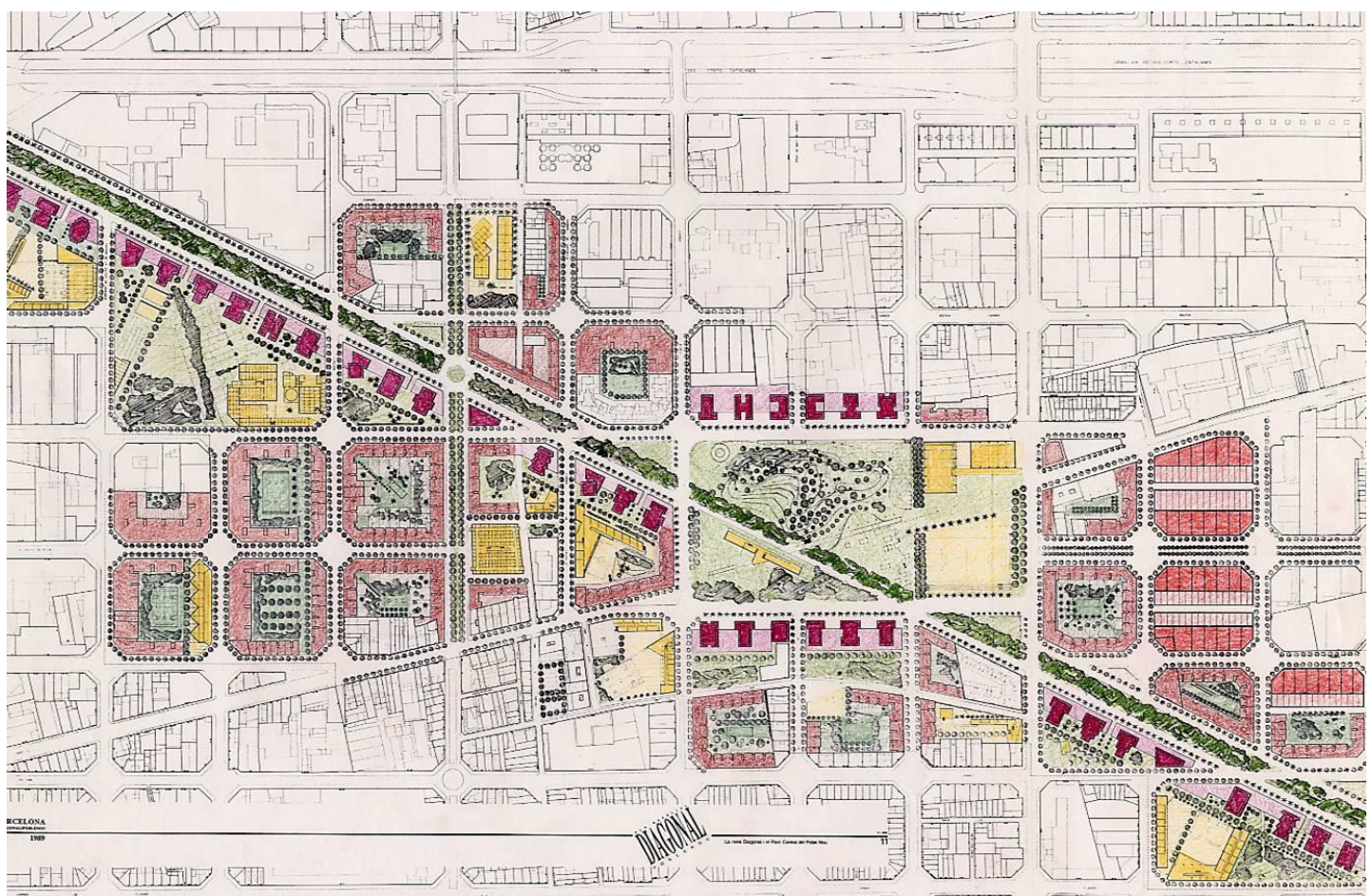

Figura 27 - Versão inicial do Plano Especial. Fonte: CCRS Arquitetos (1986).

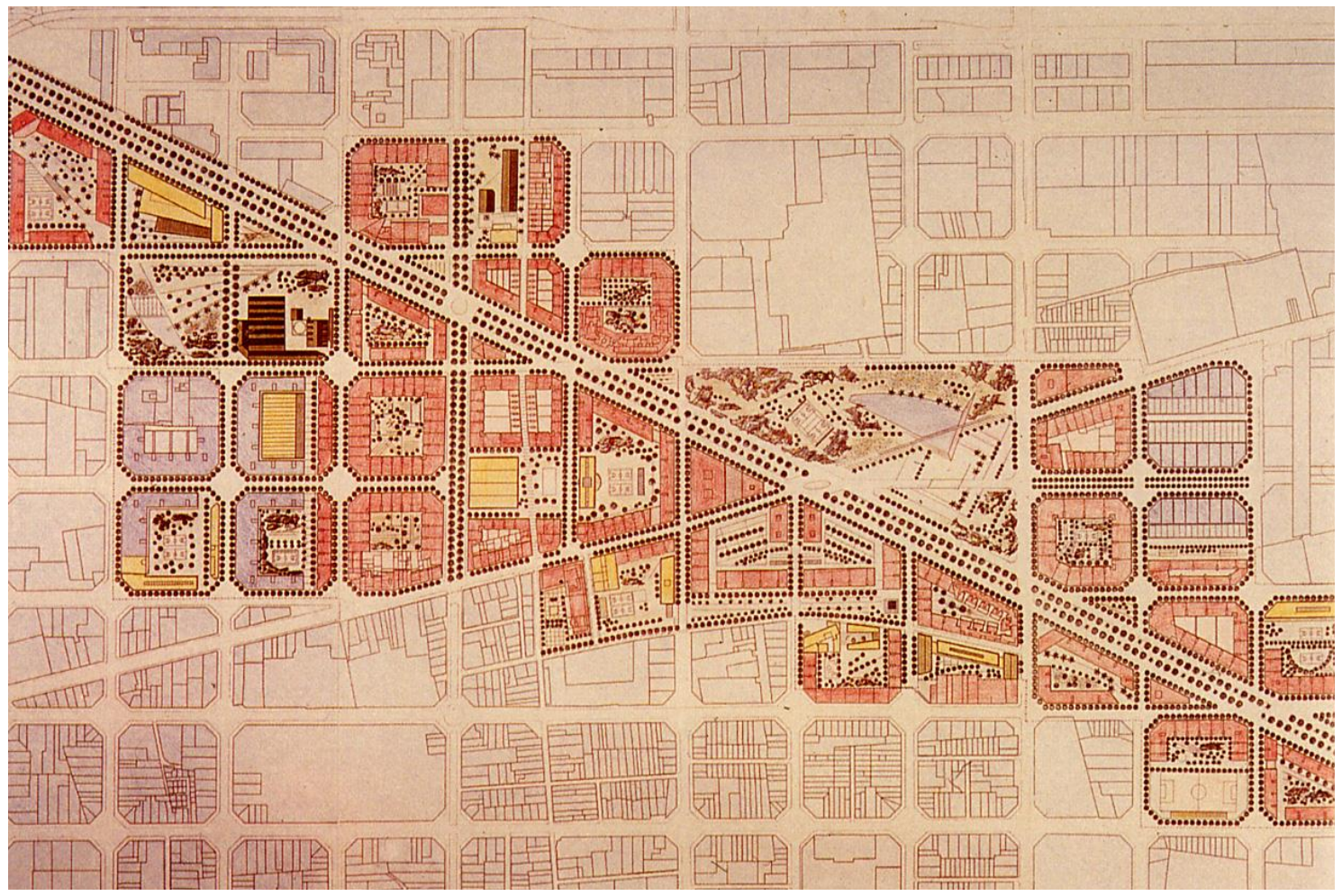

Figura 28 - Versão definitiva do Plano Especial. Fonte: CCRS Arquitetos (1986). 
Entretanto, a mudança mais importante, aquela que inclusive provoca ao final a renúncia da equipe projetista ${ }^{16}$, está no descumprimento dos objetivos sociais e no modelo de gestão aplicado. A crise econômica depois de 1992 (talvez crise de confiança na cidade em sua capacidade de seguir impulsionando projetos de transformação, ou crise de autoridade urbanística, ou de ideias), se traduz em modificações "que tornam a ação privada incompatível com a manutenção de uma determinada política habitacional" (Sabaté, 2006, tradução nossa).

As operações previstas no plano para garantir habitação social desaparecem. Os agentes privados impulsionam finalmente a transformação da área em troca de redução do nível de exigências; executam as unidades que oferecem menos dificuldades de gestão e custos; "premia-se" a aquisição recente de terrenos afetados por sistemas e praticamente vazios, com o mesmo aproveitamento médio do resto, mas com dificuldades de transformação muito menores. As áreas mais consolidadas, as mais resistentes, são deixadas sob a gestão do município.

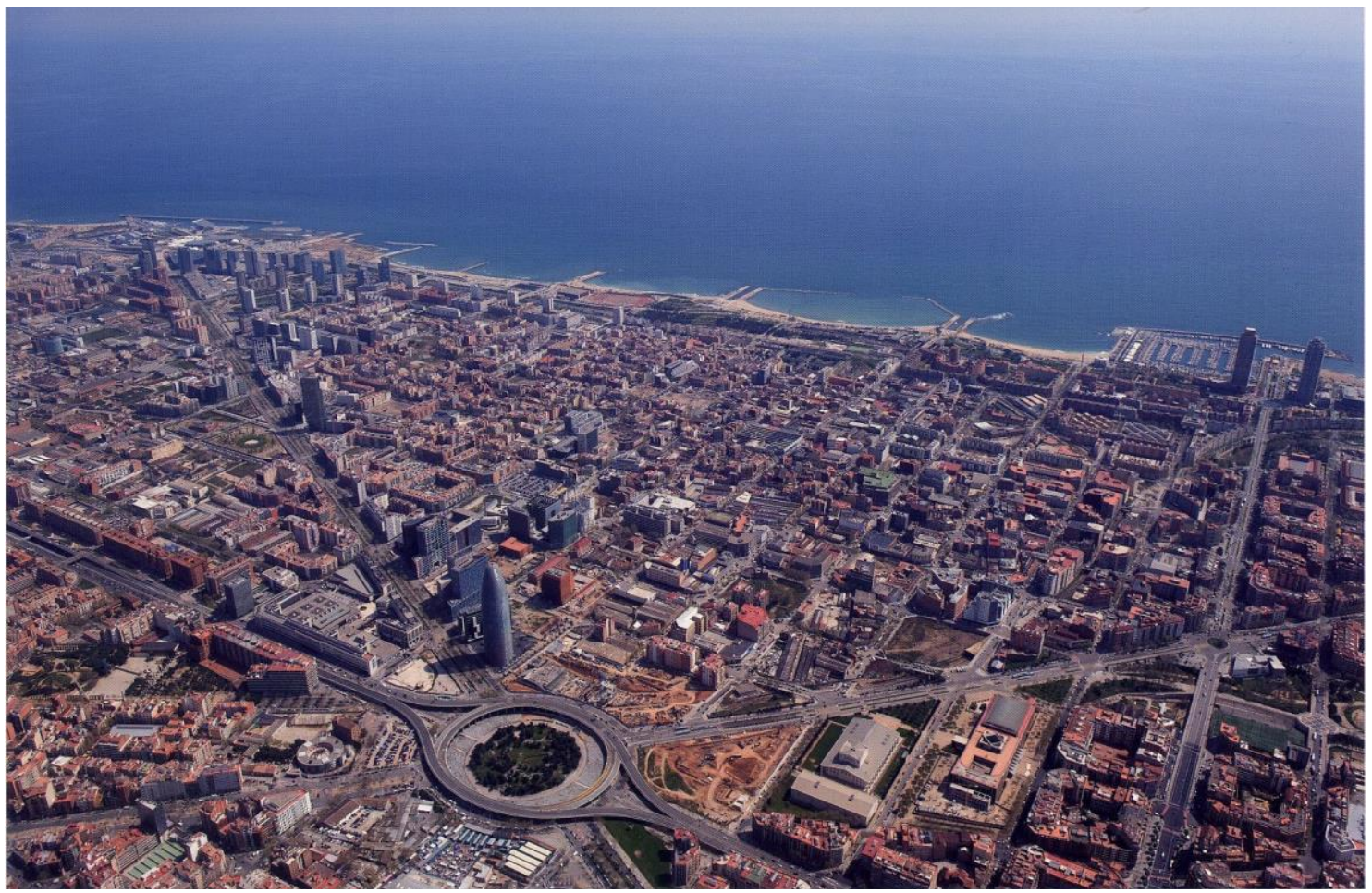

Figura 29 - Vista Avenida Diagonal 2012. Fonte: Google Maps (2020).

Visto em perspectiva atual, perde-se uma ótima oportunidade para promover uma política pública de habitação, que anos depois reclamamos com tanta urgência, ainda que em definitivo se abra uma magnífica avenida e se saneie completamente um bairro degradado (Figura 29).

Tratando de resumir as diretrizes da política urbanística desenvolvida até esse momento, cabe destacar que:

a) Barcelona começa a aproveitar a escala urbanística que se batizou como "glocalização" (global+local), situação em que os capitais globais se movem rapidamente e com grande liberdade entre lugares, criando a base para o desenvolvimento da escala local.

b) 0 município começa a ensaiar novas formas de gestão urbana, ajustando o papel dos sectores público e privado nos processos de transformação. 0 primeiro, de acordo com essas atribuições, fica

${ }^{16}$ A renúncia ocorre devido a divergências de opinião com o poder público, embora a equipe entregue toda a documentação elaborada, eliminando exclusivamente a responsabilidade da sua autoria. 
responsável pela formulação de objetivos de planeamento a médio prazo, estratégias de equilíbrio que formulam regras de ação, e o ponto de partida para a intervenção do sector privado.

c) Neste sentido, os Jogos Olímpicos não fazem mais do que atuar como catalisador, acelerador de transformações anunciadas, que em sua ausência haveriam requerido muito mais tempo para serem executadas.

d) 0 método de trabalho se embasa geralmente na combinação de diversos níveis de intervenção, de planos a médio prazo e projetos executivos, sem perder de vista a lógica geral da cidade, ainda que atuando por fragmentos. A escala intermediária constitui o âmbito básico de reflexão e proposta. A atenção às implicações estruturais das diversas intervenções se coloca ao mesmo tempo que o compromisso com uma forma urbana qualificada.

A escolha da cidade de Barcelona como sede da Olimpíada da 1992 constitui uma mudança assinalada na política urbanística municipal, que se transformará drasticamente, em curto prazo, em relação à escala e orientação das intervenções. A urgência em empreender numerosos projetos e a impossibilidade de enfrentá-los, por meio dos instrumentos tradicionais de administração, serão especialmente evidentes, ainda que de fato o ponto de inflexão claro não se produza de imediato. Talvez o entusiasmo generalizado mediante a nomeação olímpica, ou um certo reconhecimento internacional à trajetória urbanística imediatamente anterior, atenue as mudanças mais radicais.

Em 1989 já se podem apreciar algumas consequências direta ou indiretamente vinculadas à pressão olímpica: a renúncia de algum responsável político e de alguns dos técnicos mais qualificados, assim como dos autores de alguns planos de especial transcendência (como Diagonal-Poble Nou). Verificam-se ainda dificuldades para seguir mantendo os objetivos de reequilíbrio defendidos na etapa anterior; a criação de novas instituições para coordenar projetos de grande envergadura; crescente diversificação dos centros de decisão que supõe dificuldades cada vez maiores para definir estratégias unitárias; desaparecimento de âmbitos de participação social e intercâmbio crítico; inovação e organização em busca de maior eficiência, limitando o debate a um círculo cada vez menor de gestores.

A conquista dos objetivos de transformação é priorizada frente às políticas de reequilíbrio mantidas até então; a promoção econômica da cidade em face da recuperação urbanística. Novas empresas para o fomento da atividade construtiva, o compromisso de outras existentes com a política industrial, a vontade de impulsionar e participar na gestão das grandes infraestruturas constituem agora as apostas principais, e o primeiro Plano Estratégico (1988-92), o instrumento para guiá-los. O capital público se dispõe a competir em âmbitos onde estava tradicionalmente ausente, para potencializar os sectores emergentes da economia urbana, essenciais para seu desenvolvimento continuado no futuro. Daí a criação de empresas destinadas à exploração das tecnologias ou serviços gerados a partir da iniciativa municipal, e bem por isso os esforços consideráveis no "marketing" da cidade para enfrentar a concorrência derivada da globalização da economia.

Em março de 1989 um espectador privilegiado da transformação urbanística de Barcelona elogia o esforço realizado e os resultados obtidos na década de oitenta. Mas, ao mesmo tempo, expressa seu medo de que o extraordinário impulso coletivo de renovação da cidade, mantido durante dez anos, esteja desaparecendo em face "a sucessão de complexidades, obstáculos, contradições, favoritismos e burocracia administrativa e política, decisões de poder que supõe uma certa tendência ao espetáculo e à política entendida como uma simples questão de consenso" (Gregotti, citado em Sabaté e Tironi, 2008, p. 241, tradução dos autores).

\section{Considerações finais}

Se trata de um medo infundado ou ocorreu de fato uma mudança nos procedimentos de gestão e produção do espaço urbano? 
De fato, atualmente já se pode reconhecer que os padrões das intervenções que haviam caracterizado as transformações urbanas até 1986 passam a um segundo lugar; que os novos projetos prioritários se desenvolvem a um ritmo e escala que dificultam negociações cuidadosas, ou processos de tomada de decisões suficientemente pausados. A prefeitura começa a ter como interlocutores grandes promotores imobiliários, os únicos capazes de promover operações de notável envergadura com a urgência necessária. Vê-se então forçada a criar novas empresas e sociedades específicas para coordenar um trabalho de grandes dimensões, sem conseguir estabelecer mecanismos de intervenção precisos e suficientemente claros, entre um número tão grande de diferentes operadores urbanos. 0 surgimento de centros de execução e controle autônomos, a introdução de sistemas de gestão por objetivos, a implantação de contratos-programa, supõem de início conflitos e mudanças consideráveis, que vão exigir um tempo mais ou menos longo de adaptação.

Grupos mistos formados por bancos, imobiliárias, companhias de seguros e grandes construtoras se convertem nos novos protagonistas da transformação urbana, para os quais o município concede, em certas ocasiões, excessivas facilidades em detrimento do interesse público. Coincidem efetivamente desde então um conjunto de indicadores contrapostos; incremento crescente de atividades e conversão da cidade em um centro terciário em escala metropolitana e em uma capital com turismo permanente, sem períodos sazonais; aceleração na perda de população frente a um número crescente de consumidores, trabalhadores e visitantes; manutenção de um considerável nível de atividade construtiva, inclusive em momentos de recessão geral da economia; aumento notável do custo de vida; transporte público que sensivelmente perde espaço para o transporte privado; notável melhoria quanto à habitabilidade, juntamente com desafios importantes quanto às condições ambientais. A cidade como um todo obtém grandes benefícios, mas perde população e as camadas sociais mais desfavorecidas sofrem um progressivo empobrecimento.

Dos livros publicados naqueles momentos, um em particular, Barcelona New Projects (Ayuntamiento de Barcelona, 1994), resulta especialmente representativo das mudanças produzidas. De forma sintomática, o livro e a exposição que constitui seu catálogo são promovidos e financiados por novos agentes privilegiados na construção da cidade (grandes promotores, grupos financeiros, empresas públicas, empresas estrangeiras...). Alguns dos projetos incluídos na publicação seguem sendo protagonizados pelo município, mas a maior parte é de responsabilidade dos novos operadores. Isso reforça uma imagem dinâmica: a cidade atrai grandes investidores e incorporadores, apesar da desaceleração da economia.

Em contrapartida, as implicações negativas dos fenômenos da globalização já são denunciadas publicamente.

O município reduz seu protagonismo, mas tenta manter o papel de orientar intervenções, uma certa cumplicidade positiva com múltiplos agentes, buscando um acordo para recuperar, em benefício da comunidade, parte dos ganhos de capital gerados pela transformação urbana.

Em 1996, com a publicação do livro "Barcelona, a segunda renovação", ou mais tarde com o livro "Barcelona 1979/2004, do desenvolvimento à cidade de qualidade" (Ayuntamiento de Barcelona (1993a, 1999), o município tenta recuperar uma imagem de protagonismo público nas grandes decisões urbanísticas. Recupera a atenção para questões como moradia e projetos de bairro, e estabelece um maior cuidado com as intervenções privadas e se enfrenta de forma responsável o desafio ambiental.

Talvez ainda fosse cedo para falar de uma verdadeira segunda renovação, ainda que, nas palavras do então Prefeito Pascual Maragall, o importante é que Barcelona, apesar da grave crise econômica entre 1992 e 1996, manteve a confiança em si mesma, tratando de impor uma cultura de diálogo entre o público e privado, o centro e a periferia, os carros e as bicicletas ou os pedestres.

A partir do ano 2000, um outro projeto que se denomina 22@Barcelona, exemplificará as características de um novo tempo. 
Entretanto, esta é uma outra etapa da história deste processo de transformação urbana, que mostra a recuperação da iniciativa pública no projeto urbano, e que exige outro artigo para ser convenientemente analisada.

\section{Referências}

Ayuntamiento de Barcelona (1999). Barcelona 1979/2004, del desarrollo a la ciudad de calidad. Barcelona.

Ayuntamiento de Barcelona (1996). Barcelona. La segunda renovación. Barcelona.

Ayuntamiento de Barcelona (1994) Barcelona New Projects. Barcelona: Impremta Municipal.

Ayuntamiento de Barcelona (1993a). Barcelona espacio público. Barcelona.

Ayuntamiento de Barcelona (1993b). La rehabilitación del Ensanche. Barcelona.

Ayuntamiento de Barcelona (1993c). Barcelona, ponte guapa. Barcelona.

Ayuntamiento de Barcelona (1990a). Barcelona. La ciudad y el 92. Barcelona.

Ayuntamiento de Barcelona (1990b). Plan Especial del equipamiento comercial. Barcelona.

Ayuntamiento de Barcelona (1989). Ordenación urbanística de los equipamientos hospitalarios. Barcelona.

Ayuntamiento de Barcelona (1987a). Urbanismo en Barcelona: Planes hacia 1992. Barcelona.

Ayuntamiento de Barcelona (1987b). Obras, Planes y Proyectos 1981-86. Barcelona.

Ayuntamiento de Barcelona (1987c). Áreas de Nueva Centralidad. Barcelona.

Ayuntamiento de Barcelona (1984). Las vías de Barcelona. Barcelona.

Ayuntamiento de Barcelona (1983a). Planes y Proyectos para Barcelona 1981-1982. Barcelona.

Ayuntamiento de Barcelona (1983b). Estudio del Ensanche. Barcelona.

Bonet, M. R., \& Domingo, M. (1998). Barcelona i els moviments socials urbans. Barcelona: Fundació Jaume Bofill.

Capel, H. (2005). El modelo Barcelona: un examen crítico. Barcelona: Ediciones del Serbal.

CCRS Arquitectos. (1986). Memoria del Plano de Reforma Interior Diagonal-Pueblo Nuevo. Barcelona.

Corominas, M., Sabaté, J., \& Sotoca, A. (2007). Planes muy especiales (Papers Sert 16). Barcelona: Escola Sert, Colegio Oficial de Arquitectos.

Delgado, M. (2007). La ciudad mentirosa: fraude y miseria del modelo Barcelona. Madrid: Los libros de la Catarata.

Google Maps Web. (2020). Fonte de diversas fotografias. https://www.google.es/maps/@41.4267695,2.1561344,14z

Instituto Cartográfico de Catalunha. Consultar em https://www.icgc.cat/es/Ciudadano/Educacion/Fotos-y-mapasantiguos.

McHarg, I. L. (1967) Design with nature. New York: John Wiley \& Sons, Inc., 1992 (originalmente Garden City, N.Y).

Montaner, J. M., Álvarez, F, \& Muxl, Z. (eds.) (2011). Archivo crítico del modelo Barcelona 1973-2004. Barcelona: Ajuntament de Barcelona, 2011.

Sabaté; J., Pesoa, M., \& Novick, A. (2016). Algunos retos en la representación del territorio: el dibujo como instrumento interpretativo, narrativo y de proyecto. Estudios del hábitat, 14(2), e012.

Sabaté, J. (2008). Globalización y estrategias urbanísticas: un balance del desarrollo reciente de Barcelona. Cuaderno Urbano, 7, 233-260. Buenos Aires.

Sabaté, J., \& Tironi, M. (2008). Rankings, creatividad y urbanismo. EURE Revista Latinoamericana de Estudios UrbanoRegionales, 34(102), 5-23.

Sabaté, J. (2007). De la plaza de las Glorias al Forum. Luces y sombras en el proyecto urbanístico reciente de Barcelona. Cartas Urbanas, 11, 26-49. 
Sabaté, J. (2006). Luces y Sombras en el Proyecto Urbanístico Reciente de Barcelona. In M. Carmona, \& A. Arrese, Globalización y Grandes Proyectos Urbanos: La respuesta de 25 ciudades. Buenos Aires: Ediciones Infinito.

Sabaté, J. (2003). Balance y perspectivas del planeamiento urbanístico municipal. In A. Font (coord.), Planeamiento urbanístico: De la controversia a la renovación. Barcelona: Diputación de Barcelona.

Sabaté, J. (1997). L'obertura de la Diagonal al Poble Nou en Expansió urbana i planejament a Barcelona, (pp. 141-158). Barcelona: Institut de Cultura de Barcelona y Ediciones Proa.

Solà-Morales, M. (1981) La identitat del territori català. Les comarques (4-13; 59-60). Quaderns d'Arquitectura i Urbanisme, 1.e 2020.

Editor responsável: Rodrigo Firmino

Recebido: 16 dez. 2019

Aprovado: 15 out. 2020 